\title{
Evolution of fluvial environments and history of human settlements on the Ticino river alluvial plain
}

\author{
Dorota Czerski, Daphné Giacomazzi, and Cristian Scapozza \\ Institute of Earth Sciences, University of Applied Sciences and Arts of Southern Switzerland (SUPSI), \\ Campus Mendrisio, Mendrisio, 6850, Switzerland \\ Correspondence: Dorota Czerski (dorota.czerski@supsi.ch)
}

Received: 27 February 2021 - Revised: 25 July 2021 - Accepted: 19 October 2021 - Published: 6 January 2022

\begin{abstract}
The present contribution aims to provide better knowledge on the evolution of the fluvial environments of the Ticino river alluvial plain, highlighting the complex interaction of the Ticino river and its lateral tributaries with the human communities since the Neolithic. The study considers information derived from historical sources, from previous research on three sites based in the Ticino river floodplain and from data of six archaeological sites located on four alluvial fans. For the investigated sites the analyses of the lithostratigraphy and the archaeological evidence were constrained with radiocarbon dating, providing the interpretation of the depositional context of the studied sequences and their correlation with the cultural periods and epochs defined for the southern Swiss Alps. The combined approach allowed for the definition of 13 phases of enhanced hydro-sedimentary activity from the Neolithic to the contemporary period. The possible palaeoenvironmental and palaeoclimatic causes, as well as the impacts of these phases on the human settlements, are discussed.
\end{abstract}

\section{Introduction}

The rather capricious nature of the upper part of the Ticino river (Switzerland) has been known since ancient times (e.g. Martinoli, 1896; Grossi, 1986). The river originates at the Nufenen Pass at almost $2500 \mathrm{~m}$ a.s.l. in the heart of the Alps and flows into Lake Maggiore (193 m a.s.l.) in an almost Mediterranean climate (Scapozza, 2016; Scapozza and Ambrosi, 2021, and references therein). For thousands of years, together with its main tributaries and the streams coming from lateral valleys, the river set the rhythm for the life of the inhabitants of the alluvial plain from Biasca to Magadino (Fig. 1). The major floods have been repeated for centuries and have favoured the lateral displacement of the bed on both sides of the valley, creating new fluvial landforms and also modifying the topography of the floodplain (Scapozza, 2013; Scapozza and Oppizzi, 2013). This capricious behaviour of the Ticino river became increasingly in conflict with human activities until the flood of 1868, which is known as "la grande alluvione" (lit.: the great flood). After this event, it was decided to definitively correct the river and embank it along its entire length (e.g. Martinoli, 1896;
Grossi, 1986; Minor et al., 2004; Piffaretti and Luchessa, 2011; Scapozza, 2013).

The Ticino river dynamics are well known only after the middle of the 19th century (Minor et al., 2004; Piffaretti and Luchessa, 2011). However, information concerning the river dynamics and morphology before its embankment are limited to recent studies, focusing on the sedimentary and geomorphological analysis of the Ticino river floodplain filling (Scapozza and Oppizzi, 2013; Scapozza et al., 2017) or on the analysis of historical documents, with a particular focus on historical cartography, since the Roman Period (Scapozza, 2013). The colonisation history of the bottom of the valley is nevertheless well known thanks to the numerous archaeological discoveries that made possible the reconstruction of the human settlements occupying the Ticino valley since the $\mathrm{Ne}$ olithic (e.g. Donati, 1986; Crivelli, 1990; De Marinis and Biaggio Simona, 2000; Carlevaro, 2013). In addition to archaeological investigation, the dynamics of the vegetation evolution during the Holocene (with a focus on forest fires) are furthermore well known mostly thanks to palynological studies carried out in ponds, marshes and peat bogs (e.g. Tinner et 


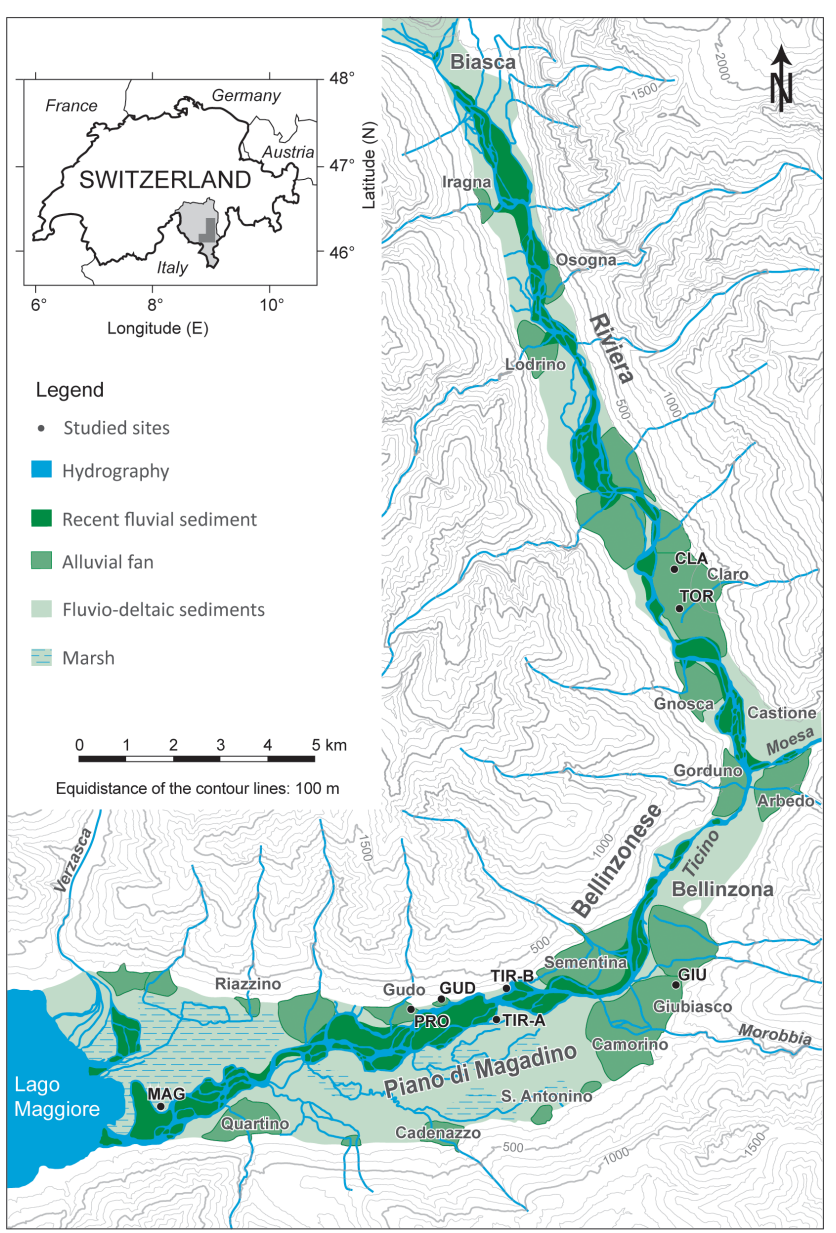

Figure 1. Main hydrographical and geomorphological landforms of the Ticino river floodplain and location of the sites of investigation. Situation of the floodplain in $1854 \mathrm{CE}$, just before the river embankment of the second half of the 19th century (modified from Scapozza and Oppizzi, 2013). Study sites (from west to east): $\mathrm{MAG}=$ Magadino, $\mathrm{PRO}=$ Gudo, Progero; GUD = Gudo, Paese, Via alla Chiesa; TIR-A = Gaggiolo Lungo, Gudo; TIR-B = Boschetti, Sementina; GIU = Giubiasco, Palasio; TOR $=$ Claro, Torrazza; CLA = Claro, Longo and In Rasaréi.

al., 1999, 2003; Conedera and Tinner, 2000; Morales-Molino et al., 2015).

In the current context of a climate change which is getting warmer and warmer (Académies suisses des sciences, 2016), it is important to understand the intrinsic relationships between the climate oscillations and the fluvial activity, in particular when the latter increases and can cause repeated floods (e.g. Arnaud et al., 2005; Wirth et al., 2013). Within this framework, the fluvial activity, as well as its environment, is linked to the human communities in terms of resources and natural risks (e.g. Bravard and Petts, 1996; James and Marcus, 2006). Considering also the renewed interest for revitalisation and renaturation projects of fluvial hydrosystems (UFAM, 2017), this study aims to improve our knowl- edge of past river dynamics and to understand their recent evolution and possibly predict their future dynamics, as was done for other Alpine rivers (e.g. Bravard et al., 1992; Glaser et al., 2005; Laigre et al., 2012). The main objective is to determine the morphosedimentary dynamics of the Ticino river and its tributaries, as well as their interaction with the human communities, since the Neolithic. It will be achieved through the study of fluvial deposits in archaeological sites thanks to the following evaluations: (1) the definition of phases of enhanced hydro-sedimentary activity; (2) the analysis of their palaeoenvironmental and palaeoclimatic causes; and (3) the determination of their relationships with the human communities in terms of protection from the floods and impact of this natural phenomenon on anthropic constructions.

\section{Study area}

The Ticino fluvio-deltaic plain includes the Ticino river floodplain between Biasca (confluence of Ticino and Brenno rivers) and Giubiasco (valley bottom of the Riviera and Bellinzonese), as well as the Ticino (and Verzasca) river delta between Camorino and Lake Maggiore, known as Piano di Magadino (Fig. 1). In the upper part (Riviera), the valley is oriented north-northwest-south-southeast. Despite its embankment, the current morphology of the Ticino river through Riviera is meandering between the lateral alluvial fans which force the watercourse to switch from the right side to the left side of the valley, and vice versa. The width of the floodplain rarely exceeds $1 \mathrm{~km}$ and contracts to a few hundreds of metres near the distal part of the alluvial fans. Between Gnosca and Gorduno, the valley is oriented northsouth. The Ticino river is constrained by the action of the Moesa river (tributary on the left side of the Ticino river) and by the presence of the Arbedo and Gorduno alluvial fans, facing each other and occupying the valley. From Gorduno, the valley forms a bend and is oriented northeast-southwest until Camorino. As upstream, the morphology is conditioned by the presence of impressive alluvial fans. Downstream from the confluence between the Ticino river and the Morobbia river, the floodplain is oriented east-west until Lake Maggiore. The current fluvial morphology is characterised by a single straight channel due to the river embankment.

The Piano di Magadino is a huge fluvio-deltaic plain formed by the progradation of the Ticino and Verzasca deltas during the Holocene (Scapozza and Oppizzi, 2013; Scapozza, 2016; Scapozza and Czerski, 2019; Scapozza and Ambrosi, 2021). Its width is variable from $2.5 \mathrm{~km}$ in the narrowest sectors to $3.5 \mathrm{~km}$ in the widest sector. The great mobility of the active band of the Ticino river during the Late Holocene, as well as the relatively frequent floods (e.g. Scapozza, 2013; Scapozza and Oppizzi, 2013), has favoured the development of the settlements on the structural terraces on the lower part of the valley sides or on the alluvial fans of the tributaries (e.g. Carlevaro, 2013). 
This study considers information coming from three sites described in previous research concerning the sedimentary filling of the Ticino river floodplain (Scapozza and Oppizzi, 2013; Scapozza, 2016; Scapozza et al., 2017), as well as information from six archaeological sites located on four alluvial fans of the Ticino river tributaries, which have been the subject of recent excavations (Cardani Vergani, 2018, 2020, 2021; Scapozza and Czerski, 2019).

The three sites located on the Ticino river floodplain are based in Magadino (noted MAG in this study), in Gaggiolo Lungo (TIR-A) and in Boschetti (TIR-B). The six archaeological sites are described in more detailed below.

The site of Gudo, Santa Maria (locality of Progero, PRO), is located on the alluvial fan fed by the streams coming from the Valle di Progero and just above Gudo (Cardani Vergani, 2018; Scapozza and Czerski, 2019). It presents a Bronze Age settlement.

In Gudo, a second site is studied in Via alla Chiesa (GUD). It is located on the alluvial fan at the bottom of Valle del Cugnolo. Structures of the Iron Age were discovered there, including an imposing L-shaped wall (Cardani Vergani, 2018; Scapozza and Czerski, 2019).

In Giubiasco (GIU), in the historic nucleus of Palasio (gardens of Villa Rusconi), on the alluvial fan of the FossatoSbardella stream, traces of occupation since the Bronze Age were discovered particularly with remains of structures and buildings from the Roman Period to the end of the 18th century (Cardani Vergani, 2020, 2021). The Fossato-Sbardella stream (Italian "Riale Fossato-Sbardella", also known as Palasio stream, "ruscello del Palasio" in Italian) was at the origin of floods causing considerable damages during the last centuries (Documentazione IVS Cantone Ticino, 1999).

In the locality of Claro, three archaeological sites were investigated. The two sites of "Longo" (CLA-L) and of "In Rasaréi" (CLA-R) presented structures of the Neolithic and of the Iron Age (Cardani Vergani, 2019, 2020, 2021); the site "Longo", in particular, was the scene of the discovery of a megalithic site unique for the south of the Alps (Cardani Vergani, 2020, 2021). In the site of "Scerese" in the hamlet of Torrazza (TOR), in addition to the discovery of an Early Iron Age settlement, a $20 \mathrm{~m}$ long and 3-4 m high trench was opened on the fluvial deposits forming the near-surface part of the alluvial fan of Claro (Cardani Vergani, 2020), which is the largest in the Canton of Ticino and whose development after the last deglaciation has been the subject of recent studies (Scapozza, 2016; Carlevaro et al., 2017; Scapozza and Czerski, 2019).

\section{Materials and methods}

\subsection{Sedimentological description}

Sedimentological descriptions are based on lithofacies codes proposed by Miall $(1977 \mathrm{a}, \mathrm{b})$ for the characterisation of fluvial depositional environments, with the modifications pro-

\begin{tabular}{|l|l|l|l|l|}
\hline Colour & Name & CMYK & RGB & Hex \\
\hline & dark grey & $0-0-0-75$ & $100-99-99$ & \#646363 \\
\hline & grey & $0-0-0-50$ & $157-157-156$ & \#9D9D9C \\
\hline & light grey & $0-0-0-25$ & $208-208-208$ & \#D0D0D0 \\
\hline & dark brown & $40-50-80-60$ & $61-51-20$ & \#3D3314 \\
\hline & brown & $40-50-80-30$ & $107-89-36$ & \#6B5924 \\
\hline & light brown & $40-50-80-0$ & $153-128-51$ & \#998033 \\
\hline & dark beige & $30-40-60-0$ & $179-153-102$ & \#B39966 \\
\hline & beige & $15-30-60-0$ & $217-179-102$ & \#D9B366 \\
\hline & light beige & $9-12-60-0$ & $232-224-102$ & \#E8E066 \\
\hline
\end{tabular}

Figure 2. Colour codes for the deposit descriptions used in this study (Figs. 4-6). Source: field chart of the Swiss Association of Geologists CH-GEOL.

posed by Schoeneich (1998) and Scapozza et al. (2009) (Table 1). Lithofacies allow a direct description of the texture ( $\mathrm{G}=$ gravel, $\mathrm{S}=$ sand, $\mathrm{F}=$ fine sediments), the matrix structure $(\mathrm{m}=$ matrix supported, $\mathrm{c}=$ clast supported $)$ and the sedimentary structure(s), as well as stratification, lamination, normal or inverse grading, etc. The lithofacies codes make it possible to link the deposits with the sedimentation environment and/or process and therefore to interpret its genesis. The matrix colour of the deposits is based on the field chart of the Swiss Association of Geologists CH-GEOL (Fig. 2). When the colour of the deposit is not specified, it is because the information is missing or because there is no matrix. Grain size description is based on grain size classes defined by Cailleux and Tricart (1963) and modified by King (1966): boulders (>200 mm), cobbles $(200-60 \mathrm{~mm})$, coarse gravel $(60-20 \mathrm{~mm})$, medium gravel $(20-6 \mathrm{~mm})$, fine gravel $(6-2 \mathrm{~mm})$, coarse sand $(2-0.6 \mathrm{~mm})$, medium sand $(0.6-0.2 \mathrm{~mm})$, fine sand $(0.2-0.06 \mathrm{~mm})$, silt $(0.06-0.002 \mathrm{~mm})$ and clay $(<0.002 \mathrm{~mm})$.

The sedimentological descriptions are presented in Sect. 4.2 (Figs. 4-6). A defined legend of patterns was used depending on the origin and the grain size of the deposit (Fig. 3). The represented thickness of the deposit layers is relative. Therefore, the scale used for the stratigraphic representations is not a function of a depth scale but depends on a timescale. Three of the stratigraphic representations are based on core logging, while all the others sites have been described from a section or a trench.

\subsection{Radiocarbon dating}

The age and stratigraphy of the deposits were determined using the radiocarbon dating method on organic matter debris and charcoals. Radiocarbon dating was performed by accelerator mass spectrometry (AMS) technique by the laboratories in Poznań, Poland (Poznań Radiocarbon Laboratory, laboratory codes: Poz-*), and in Miami, Florida (Beta Analytic Inc, laboratory codes: Beta-*). Radiocarbon ages measured and corrected with $\delta^{13} \mathrm{C}$ (conventional ages) are expressed in radiocarbon years before present $\left(a^{14} \mathrm{CBP}\right)$, whereas the calibrated ages are expressed in calendar years 
Table 1. Lithofacies codes for the deposits description used in this study. Modified from Miall (1977a, b), Schoeneich (1998), and Scapozza et al. (2009).

\begin{tabular}{|c|c|c|c|}
\hline $\begin{array}{l}\text { Facies } \\
\text { code }\end{array}$ & Lithofacies & Sedimentary structures & Interpretation \\
\hline $\mathrm{Gmc}$ & $\begin{array}{l}\text { Massive, clast-supported cobbles } \\
\text { and/or gravel (but with matrix) }\end{array}$ & $\begin{array}{l}\text { Horizontal bedding, } \\
\text { imbrication }\end{array}$ & $\begin{array}{l}\text { Braided river deposit in an active band } \\
\text { composed by gravelly sandy banks }\end{array}$ \\
\hline $\mathrm{Gmm}$ & $\begin{array}{l}\text { Massive, matrix-supported } \\
\text { cobbles and/or gravel }\end{array}$ & None & $\begin{array}{l}\text { Bimodal transport, mass transport (debris } \\
\text { flow) }\end{array}$ \\
\hline Gt & Cobbles and/or gravel, stratified & Trough crossbeds & Minor channel fills \\
\hline $\mathrm{Sm}$ & Massive sand & None & Channel bottom filling \\
\hline $\operatorname{Sm}(c)$ & $\begin{array}{l}\text { Massive sand with sparse coarse } \\
\text { clasts }\end{array}$ & None & Channel bottom filling \\
\hline $\mathrm{Sp}$ & Planar crossbedded sand & Planar crossbeds & $\begin{array}{l}\text { Transverse bars, sand waves (lower flow } \\
\text { regime) }\end{array}$ \\
\hline $\mathrm{Sl}$ & Laminated sand & $\begin{array}{l}\text { Low-angle }\left(<10^{\circ}\right) \text { crossbeds or } \\
\text { horizontal lamination }\end{array}$ & Scour fills \\
\hline $\mathrm{Sh}$ & $\begin{array}{l}\text { Sand, very fine to very coarse, } \\
\text { may be gravelly }\end{array}$ & $\begin{array}{l}\text { Horizontal lamination, parting } \\
\text { or streaming lineation }\end{array}$ & $\begin{array}{l}\text { Planar bed flow in secondary channel or } \\
\text { extra-channel }\end{array}$ \\
\hline $\mathrm{Fm}$ & Massive fine sediment (silt, clay) & None & $\begin{array}{l}\text { Rapid decantation overbank or by drape } \\
\text { deposit (swamp/pond deposit; colluvium) }\end{array}$ \\
\hline $\mathrm{Fl}$ & $\begin{array}{l}\text { Laminated fine sediment (silt, } \\
\text { clay) }\end{array}$ & $\begin{array}{l}\text { Fine horizontal lamination, } \\
\text { very small ripples }\end{array}$ & $\begin{array}{l}\text { Overbank or waning flood deposits (rapid } \\
\text { decantation) }\end{array}$ \\
\hline A & Anthropic structure & None & Structure built from human activity \\
\hline $\mathrm{P}$ & Pedogenetic unit & $\begin{array}{l}\text { Primary structure modified by } \\
\text { pedogenesis }\end{array}$ & Soil, palaeosoil \\
\hline $\mathrm{R}$ & Backfilling, arable, man-made sensu lato & None & Human activity \\
\hline
\end{tabular}

\begin{tabular}{|c|c|}
\hline Pattern & Name \\
\hline 773333337377777373\} & soil (root) \\
\hline 11111 & organic material \\
\hline 132808 & clay \\
\hline$= \pm=1=$ & silt \\
\hline & fine sand \\
\hline & medium sand \\
\hline$\because \therefore \therefore \therefore \therefore \therefore$ & coarse sand \\
\hline $\begin{array}{llllllll} & 0 & 0 & 0 & 0 & & \\
& 0 & 0 & 0 & 0 \\
\end{array}$ & gravel 2-5mm \\
\hline$\left[\begin{array}{llll}0 & 0 & 0 & 0 \\
& 0 & 0 & 0\end{array}\right.$ & gravel $5-10 \mathrm{~mm}$ \\
\hline $\begin{array}{llll}0 & 8 & 0 & 0 \\
& 0 & 0\end{array}$ & gravel $10-25 \mathrm{~mm}$ \\
\hline 0 & gravel $25-63 \mathrm{~mm}$ \\
\hline$\because \quad \div$ & moraine \\
\hline 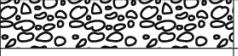 & anthropic structure \\
\hline is & sample \\
\hline
\end{tabular}

Figure 3. Legend of the patterns used for the stratigraphic logs in this study (Figs. 4-6). before present (a cal BP) or with the notation CE (common era) or BCE (before the common era). Reference geochronology, cultural chronology, climate oscillations and other regional proxies are also expressed in years (a) or millennia (ka) before 2000 CE (noted as "b2k"). Conventional age calibration was performed with OxCal 4.4 software of the Oxford Radiocarbon Accelerator Unit (Bronk Ramsey, 2001, 2020) using the IntCal20 curve (Reimer et al., 2020) and with a $2 \sigma$ confidence interval ( $95.4 \%$ of probability).

\subsection{Geoarchaeological observations and phase dating}

The sedimentological characterisation of the deposits was combined with archaeological observations and dating, allowing for the interpretation of the depositional context of the studied sequences. Relative dating coming from the archaeological seriation of assemblages and artefacts discovered on study sites was confirmed by radiocarbon dating or, in the absence of numerical dating, was used for completing the chronostratigraphy of the described sedimentary sequences (Moscato, 2002). Both numerical dating by radiocarbon and 
Table 2. Chronology of cultural periods in the southern Swiss Alps. Source: (1) Tinner et al. (2003:1454); (2) Carlevaro (2013:12).

\begin{tabular}{|c|c|c|c|}
\hline Cultural period & Age & Epoch & Source \\
\hline Neolithic & 5500-2200 BCE & & 1 \\
\hline Early Bronze Age & $2200-1550 \mathrm{BCE}$ & & 1 \\
\hline Middle Bronze Age & $1550-1300 \mathrm{BCE}$ & & 1,2 \\
\hline \multirow[t]{3}{*}{ Late Bronze Age } & 1300-900 BCE & Canegrate (1300-1200 BCE) & 2 \\
\hline & & Protogolasecca I-II (1200-1000 BCE) & \\
\hline & & Protogolasecca III (1000-900 BCE) & \\
\hline \multirow[t]{4}{*}{ Early Iron Age } & $900-450$ BCE & Golasecca IA1 (900-825/800 BCE) & 2 \\
\hline & & Golasecca IA2-IC (825/800-625 BCE) & \\
\hline & & Golasecca IIA/B/TI A (625-550 BCE) & \\
\hline & & Golasecca IIB-IIIA1/TI B/C (550-450 BCE) & \\
\hline \multirow[t]{3}{*}{ Late Iron Age } & $450-15 \mathrm{BCE}$ & Golasecca IIIA2/A3/TI D-La Tène B (450-280/250 BCE) & 2 \\
\hline & & La Tène C-La Tène D1 (280/250-70/80 BCE) & \\
\hline & & La Tène D2-Augustan epoch (70/80-15 BCE) & \\
\hline Roman Period & $15 \mathrm{BCE}-375 \mathrm{CE}$ & Augustan-Tiberian epoch (15 BCE-37 CE) & 1,2 \\
\hline Migration Period & $375-568 \mathrm{CE}$ & & 1 \\
\hline Early Middle Ages & $568-1000 \mathrm{CE}$ & & \\
\hline High Middle Ages & $1000-1250 \mathrm{CE}$ & & \\
\hline Late Middle Ages & $1250-1492 \mathrm{CE}$ & & \\
\hline Modern period & $1492-1789 \mathrm{CE}$ & & \\
\hline Contemporary period & 1789 CE-today & & \\
\hline
\end{tabular}

archaeological seriation were integrated in a chronology of cultural periods and epochs defined for the southern Swiss Alps (Table 2).

With the exception of radiocarbon dating of wood or charcoal remains from hearths of anthropic settlements, all the other numerical datings were performed on charcoals or organic matter within the deposits matrix. Therefore, the resulting age cannot be considered as an event age but must be interpreted as a bulk age (Strunk et al., 2020). As a consequence, the entire time span of the calibrated age was used to define the events chronostratigraphy. In the following sections, in some cases just the median calibrated age is mentioned in order to simplify the lecture by the reader. In the case of a coarse fluvial deposits embedded in dated fine colluvium deposits and/or in palaeosoils, the age constraint of the period of enhanced stream activity was determined by the younger terminus of the lower unit and by the older terminus of the upper unit. Concerning the periods of construction with human settlement, they are assumed to be periods of low river activity. In the absence of numerical dating of the building elements, the age constraint was determined from the bulk age of the soil on which the structure was built and from the bulk age of the fluvial deposit related to the flood impacting the structure. As a consequence, the defined chronostratigraphy is not based on direct numerical dating of the phases of enhanced hydro-sedimentary activity or of the construction phases but rather on the definition of a time interval between a terminus post quem ("limit after which") and a terminus ante quem ("limit before which") (Moscato, 2002; Grant et al., 2015).

\section{Results}

\subsection{Radiocarbon dating}

The radiocarbon dating analyses presented in this contribution were performed on 27 samples: 21 collected on the archaeological sites PRO, GUD, GIU, CLA and TOR (Fig. 1) and 6 associated with the previous study sites MAG and TIR (Fig. 1; Scapozza and Oppizzi, 2013; Scapozza et al., 2017). Table 3 presents the name, the location and the type of sample, whereas Table 4 shows the analysis results and calibration for radiocarbon dating of each sample.

\subsection{Field observations}

\subsubsection{Bolle di Magadino (MAG)}

The stratigraphy presented for the site Bolle di Magadino (Fig. 1, MAG) is based on a borehole of $50 \mathrm{~m}$ described in a previous study (Scapozza and Oppizzi, 2013). From bottom 
Table 3. Nomenclature, location and characteristics of the 27 samples dated by radiocarbon in this study. The sites are listed from the west to east as they are represented in Fig. 1. Source: (1) Scapozza and Oppizzi (2013); (2) SUPSI Institute of Earth Sciences; (3) Scapozza et al. (2017); (4) Briva Sagl Archeologia e Patrimonio, with the authorisation of the Ufficio dei beni culturali, Repubblica e Cantone del Ticino, Bellinzona.

\begin{tabular}{|c|c|c|c|c|c|c|}
\hline \multirow[t]{2}{*}{$\begin{array}{l}\text { Sample } \\
\text { name }\end{array}$} & \multirow[t]{2}{*}{$\begin{array}{l}\text { Sample } \\
\text { code }\end{array}$} & \multirow[t]{2}{*}{ Locality, district } & \multicolumn{2}{|c|}{$\begin{array}{c}\text { Coordinate } \\
{[\mathrm{CH} 1903+/ \mathrm{LV} 95]}\end{array}$} & \multirow[t]{2}{*}{ Dated material } & \multirow[t]{2}{*}{ Source } \\
\hline & & & $X$ & $Y$ & & \\
\hline MAG_1 & Poz-31086 & Magadino, Castellaccio & 2710790 & 1112340 & Wood & 1 \\
\hline MAG_2 & Poz-31083 & Magadino, Castellaccio & 2710790 & 1112340 & Wood & 1 \\
\hline MAG_3 & Poz-31077 & Magadino, Castellaccio & 2710790 & 1112340 & Wood & 1 \\
\hline PRO_1 & Beta-488655 & Gudo, Progero & 2716190 & 1114560 & Charcoal & 2 \\
\hline GUD_1 & Beta-462310 & Gudo, Paese & 2716715 & 1114800 & Charcoal & 2 \\
\hline GUD_2 & Beta-462309 & Gudo, Paese & 2716715 & 1114800 & Charcoal & 2 \\
\hline GUD_3 & Beta-462308 & Gudo, Paese & 2716715 & 1114800 & Charcoal & 2 \\
\hline GUD_4 & Beta-462311 & Gudo, Paese & 2716715 & 1114800 & Charcoal & 2 \\
\hline GUD_5 & Beta-462312 & Gudo, Paese & 2716715 & 1114800 & Charcoal & 2 \\
\hline TIR_1 & Beta-441296 & Sementina, Boschetti & 2718320 & 1114930 & Organic silt & 3 \\
\hline TIR_2 & Beta-443897 & Gudo, Gaggiolo lungo & 2718010 & 1114310 & Organic silt & 3 \\
\hline TIR_3 & Beta-441293 & Gudo, Gaggiolo lungo & 2718010 & 1114310 & Wood pole & 3 \\
\hline GIU_1 & Poz-114639 & Giubiasco, Palasio & 2721940 & 1114933 & Charcoal & 2 \\
\hline GIU_2 & Poz-114629 & Giubiasco, Palasio & 2721924 & 1114935 & Hearth's remains & 2 \\
\hline GIU_3 & Poz-114640 & Giubiasco, Palasio & 2721942 & 1114933 & Charcoal & 2 \\
\hline GIU_4 & Beta-563001 & Giubiasco, Palasio & 2721950 & 1114950 & Charcoal & 4 \\
\hline GIU_5 & Poz-114628 & Giubiasco, Palasio & 2721937 & 1114930 & Charcoal & 2 \\
\hline TOR_1 & Poz-114890 & Claro, Torrazza & 2721980 & 1123440 & Charcoal & 2 \\
\hline TOR_2 & Poz-114630 & Claro, Torrazza & 2721980 & 1123440 & Charcoal & 2 \\
\hline TOR_3 & Poz-114624 & Claro, Torrazza & 2721980 & 1123440 & Charcoal & 2 \\
\hline TOR_4 & Poz-114889 & Claro, Torrazza & 2721980 & 1123440 & Charcoal & 2 \\
\hline CLA_1 & Beta-533230 & Claro, Paese & 2721840 & 1124225 & Charcoal & 4 \\
\hline CLA_2 & Beta-533229 & Claro, Paese & 2721840 & 1124225 & Charcoal & 4 \\
\hline CLA_3 & Beta-562999 & Claro, Paese & 2721875 & 1124120 & Charcoal & 4 \\
\hline CLA_4 & Beta-522007 & Claro, Paese & 2721840 & 1124225 & Charcoal & 4 \\
\hline CLA_5 & Beta-563000 & Claro, Paese & 2721875 & 1124120 & Charcoal & 4 \\
\hline CLA_6 & Beta-533231 & Claro, Paese & 2721840 & 1124225 & Charcoal & 4 \\
\hline
\end{tabular}

to the top, the simplified log (Fig. 4a) changes from a massive layer of sand with silt (Sm-Fm) to a laminated deposit of silt with fine sand $(\mathrm{Fl})$, indicating a confined environment of deposit. It is followed by a thick sequence of fluvio-deltaic deposits which is dominated by massive sands (Sm), some with massive (Fm) or laminated (Fl) silt, alternated with stratified medium to coarse sands (Sp). An important change in the nature of the deposits is observed in the upper part of the log, with the appearance of a coarser layer with sandy gravel $(\mathrm{Gmm})$ or with silty sand $(\mathrm{Sm}-\mathrm{Fl})$ of fluvial origin, suggesting the migration of the main fluvial channel and/or the increase in the solid transport energy.

The radiocarbon dating was performed on wood material found in three different layers. Two of the organic samples were located on both sides of a deposit representing a phase of enhanced hydro-sedimentary activity, while the third one was directly collected inside it (Fig. 4a and Table 3). Therefore, two phases of enhanced hydro-sedimentary activity were defined. The first phase is constrained between
$680 \mathrm{CE}$ (lower limit for sample MAG_2) and 960 CE (upper limit for sample MAG_1, Table 4), and the second one corresponds to the range of radiocarbon ages resulting from sample MAG_3, dated between 1690 and $1920 \mathrm{CE}$. These two phases are respectively attributed to the Early Middle Ages and the modern period.

\subsubsection{Gudo, Progero (PRO)}

At the site Gudo, Progero (Fig. 1, PRO), two main phases of enhanced hydro-sedimentary activity directly related to coarse alluvial deposits could be observed. The first phase consists of a palaeochannel at the bottom of the stratigraphy, classified as Gmc (Table 1 and Fig. 4b). The fine sandy to silty layers (Sm-Fm) overlaying it indicate a calm period which was dated by radiocarbon geochronology on charcoal (Fig. 4b and Table 3, PRO_1). The following second alluvial phase shows many events with coarse material deposits succeeding and crosscutting each other, described as Gmc, 
Table 4. Laboratory results and calibration of the 27 radiocarbon datings analysed in this study. The sites are listed from the west to the east as presented in Fig. 1. For the location and characteristics of the samples, see Table 3.

\begin{tabular}{|c|c|c|c|c|c|}
\hline $\begin{array}{l}\text { Sample } \\
\text { name }\end{array}$ & Sample code & $\begin{array}{r}\text { Conventional } \\
\text { age }\left[\mathrm{a}^{14} \mathrm{CBP}\right]\end{array}$ & $\begin{array}{r}\text { Calibrated } \\
\text { age [a cal BP] }\end{array}$ & $\begin{array}{r}\text { Calibrated } \\
\text { age }[\mathrm{BCE} / \mathrm{CE}]\end{array}$ & $\begin{array}{r}\text { Median } \\
\text { calibrated } \\
\text { age }[\mathrm{BCE} / \mathrm{CE}]\end{array}$ \\
\hline MAG_1 & Poz-31086 & $1185 \pm 30$ & $\begin{array}{r}1250-1230(0.2 \%) \\
1180-1050(86.5 \%) \\
1040-990(8.7 \%)\end{array}$ & $\begin{array}{r}700-720 \mathrm{CE}(0.2 \%) \\
770-900 \mathrm{CE}(86.5 \%) \\
910-960 \mathrm{CE}(8.7 \%)\end{array}$ & $840 \mathrm{CE}$ \\
\hline MAG_2 & Poz-31083 & $1235 \pm 30$ & $1270-1060(95.4 \%)$ & $680-890 \mathrm{CE}(95.4 \%)$ & $800 \mathrm{CE}$ \\
\hline MAG_3 & Poz-31077 & $50 \pm 30$ & $\begin{array}{r}260-220(27.3 \%) \\
140-30(68.1 \%)\end{array}$ & $\begin{array}{l}1690-1730 \text { CE }(27.3 \%) \\
1810-1920 \text { CE }(68.1 \%)\end{array}$ & $1830 \mathrm{CE}$ \\
\hline PRO_1 & Beta- 488655 & $3110 \pm 30$ & $3400-3230(95.4 \%)$ & $1450-1280$ BCE $(95.4 \%)$ & $1380 \mathrm{BCE}$ \\
\hline GUD_1 & Beta-462310 & $2440 \pm 30$ & $\begin{array}{l}2700-2630(22.3 \%) \\
2620-2560(10.9 \%) \\
2540-2350(62.3 \%)\end{array}$ & $\begin{array}{l}760-680 \text { BCE }(22.3 \%) \\
670-610 \text { BCE }(10.9 \%) \\
600-400 \text { BCE }(62.3 \%)\end{array}$ & $540 \mathrm{BCE}$ \\
\hline GUD_2 & Beta-462309 & $2250 \pm 30$ & $\begin{array}{l}2350-2290(30.5 \%) \\
2270-2150(64.9 \%)\end{array}$ & $\begin{array}{l}400-340 \text { BCE }(30.5 \%) \\
320-200 \text { BCE }(64.9 \%)\end{array}$ & $280 \mathrm{BCE}$ \\
\hline GUD_3 & Beta-462308 & $2180 \pm 30$ & $2320-2090(95.4 \%)$ & $370-150$ BCE $(95.4 \%)$ & $270 \mathrm{BCE}$ \\
\hline GUD_4 & Beta-462311 & $2060 \pm 30$ & 2120-1930 (95.4\%) & 170 BCE-20 CE (95.4\%) & $70 \mathrm{BCE}$ \\
\hline GUD_5 & Beta-462312 & $1630 \pm 30$ & $1570-1400(95.4 \%)$ & $380-550 \mathrm{CE}(95.4 \%)$ & $430 \mathrm{CE}$ \\
\hline TIR_1 & Beta-441296 & $1230 \pm 30$ & $\begin{array}{l}1270-1200(27.7 \%) \\
1190-1060(67.7 \%)\end{array}$ & $\begin{array}{l}680-750 \text { CE }(27.7 \%) \\
760-890 \text { CE }(67.7 \%)\end{array}$ & $800 \mathrm{CE}$ \\
\hline TIR_2 & Beta-443897 & $560 \pm 30$ & $\begin{array}{l}640-580(48.6 \%) \\
570-520(46.9 \%)\end{array}$ & $\begin{array}{l}1310-1370 \text { CE }(48.6 \%) \\
1380-1430 \text { CE }(46.9 \%)\end{array}$ & $1360 \mathrm{CE}$ \\
\hline TIR_3 & Beta-441293 & $100 \pm 30$ & $\begin{array}{r}270-210(26.1 \%) \\
150-20(63.3 \%)\end{array}$ & $\begin{array}{l}1680-1740 \text { CE }(26.1 \%) \\
1800-1930 \text { CE }(69.3 \%)\end{array}$ & $1840 \mathrm{CE}$ \\
\hline GIU_1 & Poz-114639 & $825 \pm 30$ & $780-680(95.4 \%)$ & $1170-1270 \mathrm{CE}(95.4 \%)$ & $1230 \mathrm{CE}$ \\
\hline GIU_2 & Poz-114629 & $705 \pm 30$ & $\begin{array}{l}690-630(76.5 \%) \\
590-560(18.9 \%)\end{array}$ & $\begin{array}{l}1260-1320 \text { CE }(76.5 \%) \\
1360-1390 \text { CE }(18.9 \%)\end{array}$ & $1290 \mathrm{CE}$ \\
\hline GIU_3 & Poz-114640 & $470 \pm 30$ & $550-490(95.4 \%)$ & $1400-1460 \mathrm{CE}(95.4 \%)$ & $1440 \mathrm{CE}$ \\
\hline GIU_4 & Beta-563001 & $330 \pm 30$ & $480-310(95.4 \%)$ & $1470-1640 \mathrm{CE}(95.4 \%)$ & $1560 \mathrm{CE}$ \\
\hline GIU_5 & Poz-114628 & $145 \pm 30$ & $290-1950(95.4 \%)$ & $1660-1950 \mathrm{CE}(95.4 \%)$ & $1810 \mathrm{CE}$ \\
\hline TOR_1 & Poz-114890 & $4680 \pm 30$ & $5480-5310(95.4 \%)$ & 3530-3360 ВCE (95.4\%) & $3440 \mathrm{BCE}$ \\
\hline TOR_2 & Poz-114630 & $2705 \pm 30$ & $2860-2750(95.4 \%)$ & 910-800 BCE $(95.4 \%)$ & $860 \mathrm{BCE}$ \\
\hline TOR_3 & Poz-114624 & $2700 \pm 30$ & $2860-2750(95.4 \%)$ & 910-800 BCE (95.4\%) & $850 \mathrm{BCE}$ \\
\hline TOR_4 & Poz-114889 & $2005 \pm 30$ & 2010-1830 (95.4\%) & 60 BCE-120 CE $(95.4 \%)$ & $10 \mathrm{CE}$ \\
\hline CLA_1 & Beta-533230 & $4240 \pm 30$ & $\begin{array}{r}4870-4800(62.4 \%) \\
4760-4700(27.6 \%) \\
4680-4650(5.5 \%)\end{array}$ & $\begin{array}{r}2920-2850 \text { BCE }(62.4 \%) \\
2810-2750 \text { BCE }(27.6 \%) \\
2730-2700 \text { BCE }(5.5 \%)\end{array}$ & $2880 \mathrm{BCE}$ \\
\hline CLA_2 & Beta-533229 & $4060 \pm 30$ & $\begin{array}{r}4800-4760(6.3 \%) \\
4690-4680(0.3 \%) \\
4630-4420(88.8 \%)\end{array}$ & $\begin{array}{r}2850-2810 \text { BCE }(6.3 \%) \\
2740-2730 \text { BCE }(0.3 \%) \\
2680-2470 \text { BCE }(88.8 \%)\end{array}$ & $2590 \mathrm{BCE}$ \\
\hline CLA_3 & Beta-562999 & $3990 \pm 30$ & $4530-4400(95.4 \%)$ & $2580-2460$ BCE (95.4\%) & $2520 \mathrm{BCE}$ \\
\hline CLA_4 & Beta-522007 & $3940 \pm 30$ & $\begin{array}{r}4520-4480(10.2 \%) \\
4450-4280(82.8 \%) \\
4270-4250(2.5 \%)\end{array}$ & $\begin{array}{r}2570-2530 \text { ВCE }(10.2 \%) \\
2500-2340 \text { ВCE }(82.8 \%) \\
2330-2300 \text { ВCE }(2.5 \%)\end{array}$ & $2430 \mathrm{BCE}$ \\
\hline CLA_5 & Beta-563000 & $3270 \pm 30$ & $\begin{array}{c}3570-3440(89.3 \%) \\
3430-3400(6.2 \%)\end{array}$ & $\begin{array}{r}1620-1490 \text { BCE }(89.3 \%) \\
1480-1450 \text { BCE }(6.2 \%)\end{array}$ & $1530 \mathrm{BCE}$ \\
\hline CLA_6 & Beta-533231 & $2600 \pm 30$ & $2770-2700(95.4 \%)$ & $820-750$ BCE (95.4\%) & $790 \mathrm{BCE}$ \\
\hline
\end{tabular}



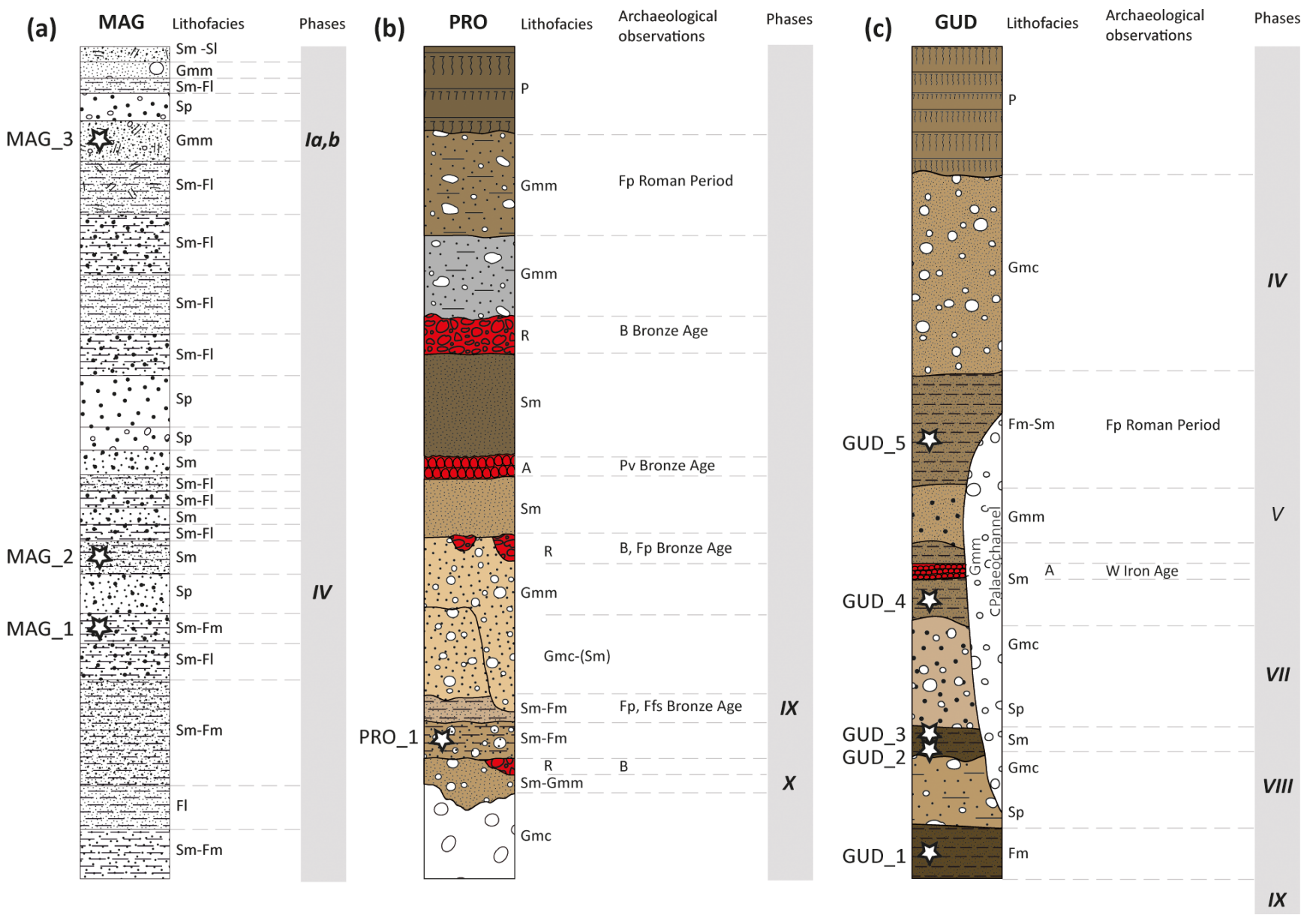

Figure 4. Stratigraphic logs in a timescale representation, with their corresponding lithofacies and archaeological remains. The phases (grey shaded) correspond to the enhanced hydro-sedimentary phases defined in Sect. 5.1. Sites: (a) Bolle di Magadino (MAG; Scapozza and Oppizzi, 2013); (b) Gudo, Progero (PRO); (c) Gudo, Paese (GUD). Codes for archaeological observations: $\mathrm{B}=$ backfilling; Ffs = fragments of flint stone; $\mathrm{Fp}=$ fragments of pottery; $\mathrm{Pv}=$ pavement; $\mathrm{W}=$ wall.

Sm and Gmm. These deposits are attributed to the lateral alluvial fans or debris flows from the valley slope. After this phase, the first records of human settlement in the area are observed and consist of anthropic backfillings containing some ceramic debris of the Bronze Age. It is then followed by two events of finer sandy deposits (Sm) which alternate with remnants of human constructions still dating from the Bronze Age. These deposits are of fluvial origin and attributed to a possible temporary palaeomeander of the Ticino river, which allowed the sudden deposition of very fine and homogeneous material by rapid decantation. The presence of anthropic pavements at that time confirms the proximal position of the human settlements to the river (both the stream from the valley slope and the Ticino river), confirmed also by the presence, less than $100 \mathrm{~m}$ to the south, of the protohistoric necropolis of Gudo (Sormani, 2007, 2012, 2013).

The radiocarbon age determined for the sample PRO_1 between 1450 and $1280 \mathrm{BCE}$ (Table 4) and attributed to the Late Bronze Age is coherent with the fragments of pottery of the Bronze Age described in the overlying deposits of anthropic origin (Fig. 4b) (Cardani Vergani, 2018; Scapozza and Czerski, 2019).

The two phases of hydro-sedimentary activity deduced from the stratigraphic sequence of PRO and subsequently constrained by the radiocarbon dating of charcoal within the finer deposits can be chronologically resumed as follows: a phase during the Middle Bronze Age and a phase during the Late Bronze Age and Early Iron Age (Fig. 4b).

\subsubsection{Gudo, Paese (GUD)}

This site (Fig. 1, GUD) is located in a more proximal position to the slope compared to the site Gudo, Progero (Fig. 1, PRO).

Four layers with coarser grain size deposits were observed, suggesting the record of four events of major hydrosedimentary activity in the area. The deposits of the first and second events are defined as Sp and Gmc towards the 
top of the layer (Table 1 and Fig. 4c), indicating an increase in the energy of the fluvial transport. The overlying coarser deposits are considered as Gmm and Gmc. They are attributed to fluvial active channels of the alluvial fan, with hyperconcentrated deposits coming from the slope of the Ticino valley. The deposits related to the four events of enhanced hydro-sedimentary activity alternate with finer sediments $(\mathrm{Fm}$ and $\mathrm{Sm})$ associated with periods of low river activity, which allowed a soil development (pedogenesis). Some charcoals found in those finer layers were sampled for the radiocarbon dating analysis (Fig. 4c and Table 3, GUD_1-GUD_5).

The radiocarbon ages determined for the samples of GUD show time ranges between 760-400 BCE (GUD_1) and 380550 CE (GUD_5, Table 4), covering a period including the Early Iron Age, the Roman Period and the Migration Period. The four events of enhanced hydro-sedimentary activity observed could have occurred in this interval of time and can be chronologically placed as follows: two phases during the Late Iron Age, a phase during the Roman Period and a phase during the Early Middle Ages (Fig. 4c). The archaeological findings are coherent with the radiocarbon ages; in particular, the L-shaped wall of the Iron Age found between the first two events confirms the dating and suggests a stable human settlement in the area during the Iron Age, as well as the need to build a dam for containing the floods, most likely coming from the Ticino river (Cardani Vergani, 2018; Scapozza and Czerski, 2019).

\subsubsection{Ticino river floodplain (TIR)}

The data for the Ticino river floodplain (Fig. 1, TIR) derive from previous studies (Scapozza et al., 2017). For the present contribution, two stratigraphic sequences typical for the Ticino river alluvial plain are shown, coming from the locality Gaggiolo Lungo in Gudo (TIR-A) and from the Boschetti area in Sementina (TIR-B).

The stratigraphy of TIR-A was described in an excavation trench of $3 \mathrm{~m}$ height (Fig. 5a). Nine units of natural deposits of swamp-fluvial origin were observed: silty layers more or less rich in organic material (Fm) alternated with silty sands (Sm). The peculiarity of the site consists of the finding of a wooden pole (sample TIR_3, Table 3) embedded in a swamp deposit (Fm) at the bottom of the stratigraphy (TIR_2). This wooden pole was subsequently covered by sandy fluvial deposits. The difference between the radiocarbon ages for the two samples, 1680-1930 CE for TIR_3 and 1310-1430CE for TIR_2 (Table 4), dates the period of calm before the subsequent enhanced hydro-sedimentary activity phase which occurred after $1680 \mathrm{CE}$, as shown by the interval of ages determined for TIR_3.

The stratigraphy of TIR-B derives from a borehole of $8 \mathrm{~m}$ (Fig. 5b). From the bottom to the top, the sequence alternates between finer sediments (Sp, Fm, Sm) and coarser deposits $(\mathrm{Gmc}, \mathrm{Gmm})$. This is due to the river dynamics which are going from calmer and confined environments such as extra-channels or swamps to fluvial active channels.

Sample TIR_1 was collected for radiocarbon dating from a fine organic layer (Fm) underlying a coarse deposit (Fig. 5b and Table 3). TIR_1 dated between 680 and 890 CE (Table 4) provides the interval of time during the Early Middle Ages, corresponding to the start of the enhanced hydro-sedimentary activity phase observed in the sequence.

\subsubsection{Giubiasco, Palasio (GIU)}

In Giubiasco, Palasio (Fig. 1, GIU), the activity and position of the Fossato-Sbardella stream had a determinant influence on the sequence of deposits and the construction and destruction phases observed (Cardani Vergani, 2020, 2021). The observations are resumed in a representative stratigraphic sequence with 10 units of natural deposits and five levels of anthropic structures (Fig. 5c and Table 3).

The stratigraphic sequence starts with a deposit of massive clast-supported boulders and cobbles within a gravelly and sandy matrix (Gmc) where fragments of amphora were found and connected to the Roman Period (1st century CE). This deposit is interpreted to be representative of a phase of enhanced hydro-sedimentary activity. It is followed by a sandy deposit with gravel (Sm-G) and laminated sand and silt (Sh-Fl). Upwards, the clasts stacking in a fluvial active band deposit (Gmc-Gmm) suggested an apparent flow direction with the beginning of the progressive migration of the stream towards the northeast. It evolves into the three layers of silty sands classified as Sm, Sm-Fm and Sh-Fl where GIU_1-GIU_4 were sampled. They are attributed to a secondary fluvial channel and interpreted to be in layers of low river activity (Fig. 5c and Table 3). GIU_1 dated between 1170 and $1270 \mathrm{CE}$ (Table 4) attests to the end of construction phases 1 and 2 and of the first phase of intense alluvial activity. GIU_2 dated from a hearth's remains found at the boundary between two layers has an age between 1260 and $1320 \mathrm{CE}$ and is evidence of the last human activity for construction phases 1 and 2. GIU_3 collected below some building material provides the evidence of the beginning of construction phase 3 after $1460 \mathrm{CE}$. Construction phase 3 lasted until 1640 CE as shown by the age interval of sample GIU_4, found at the boundary before the deposition of the fluvial sediment Sh-Fl (Fig. 5c). Construction phase 3 was partially destroyed by some alluvial events that must have occurred after $1640 \mathrm{CE}$ and before construction phase 4 . An alluvial event characterised by a sandy deposit with pebbles and gravel $(\mathrm{Sm})$ cuts all the previous layers including structures of construction phase 3 and a wall belonging to construction phase 4 (Fig. 5c). A sample of charcoal (Table 3, GIU_5) found within this sandy alluvial deposit allowed us to determine a radiocarbon age of the alluvial event between 1660 and $1950 \mathrm{CE}$, suggesting the occurrence of a phase of enhanced hydro-sedimentary activity after $1660 \mathrm{CE}$ and before $1790 \mathrm{CE}$, the year of the construction of Villa Rusconi. 

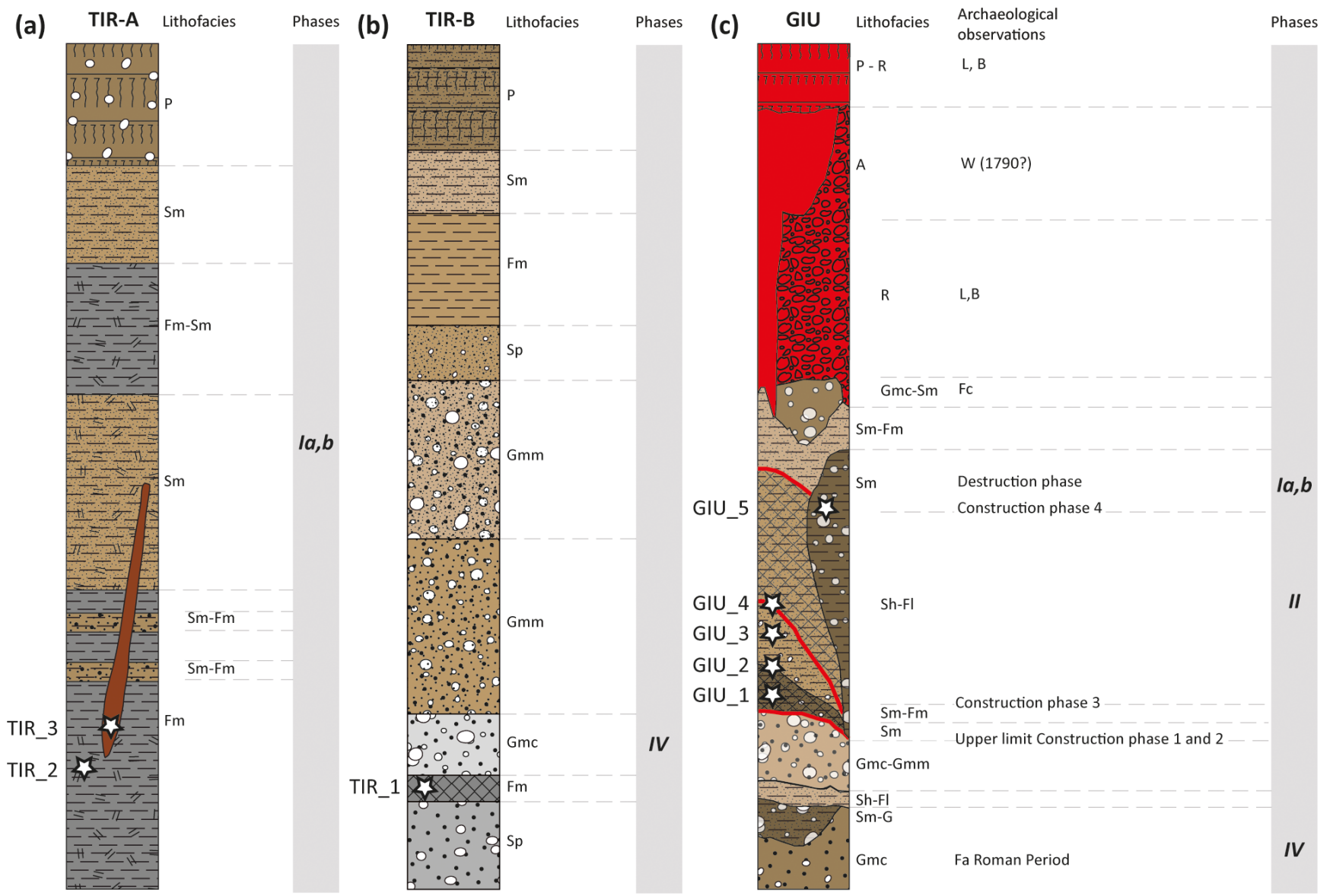

Figure 5. Stratigraphic logs in a timescale representation, with their corresponding lithofacies and archaeological remains. The phases (grey shaded) correspond to the enhanced hydro-sedimentary phases defined in Sect. 5.1. Sites: (a) Gaggiolo Lungo, Gudo (TIR-A; Scapozza et al., 2017); (b) Boschetti, Sementina (TIR-B; Scapozza et al., 2017); (c) Giubiasco, Palasio (GIU). Codes for archaeological observations: $\mathrm{B}=$ backfilling; $\mathrm{Ffs}=$ fragments of flint stone; $\mathrm{Fp}=$ fragments of pottery; $\mathrm{L}=$ levelling; $\mathrm{Pv}=$ pavement; $\mathrm{W}=$ wall.

The Giubiasco, Palasio, site provides the evidence of three events of enhanced hydro-sedimentary activity (Fig. 5c). The first is directly observed in the stratigraphic sequence and occurred during the Early and High Middle Ages. The second event must have occurred between construction phases 2 and 3 during the Late Middle Ages. The third and last event is associated with the destruction of construction phases 3 and 4 during the modern and contemporary periods.

\subsubsection{Claro, Torrazza (TOR)}

The field observations for the site Claro, Torrazza (Fig. 1, TOR), were resumed in a representative stratigraphic sequence that counts 10 units of natural deposits. No archaeological evidence is presented for this particular section (Fig. 6a).

The Gmm unit at the bottom of the sequence is characterised as a hyperconcentrated deposit $(\mathrm{Gmm})$. Afterwards, four more levels suggesting a higher energy of sedimentary transport were observed and described as $\mathrm{Gmc}, \mathrm{Sl}, \mathrm{Gmc}$,
Gmc (-Gmm), Sm-Sl and Gmc just below the superficial soil layer. The coarse-grained levels are alternated with some sandy silts (Fm), from which four samples of charcoal were collected for radiocarbon dating (Fig. 6a and Table 3).

The results indicate a range of ages between 3530 BCE (TOR_1) and 120 CE (TOR_4, Table 4), covering a period including the Neolithic, the Bronze Age and the Iron Age. The four phases of enhanced hydro-sedimentary activity observed in TOR have possibly occurred in this interval of time. The radiocarbon ages are coherent with the human settlements of the Iron Age observed in others sectors of the studied site (Cardani Vergani, 2020).

\subsubsection{Claro (CLA)}

The observations for Claro (Fig. 1, CLA) were resumed in two stratigraphic sequences according to the different areas: CLA-L for "Longo" and CLA-R for "In Rasaréi".

The stratigraphy of CLA-L (Fig. 6b) presents eight units of natural fluvial deposits. The sequence starts with two units 

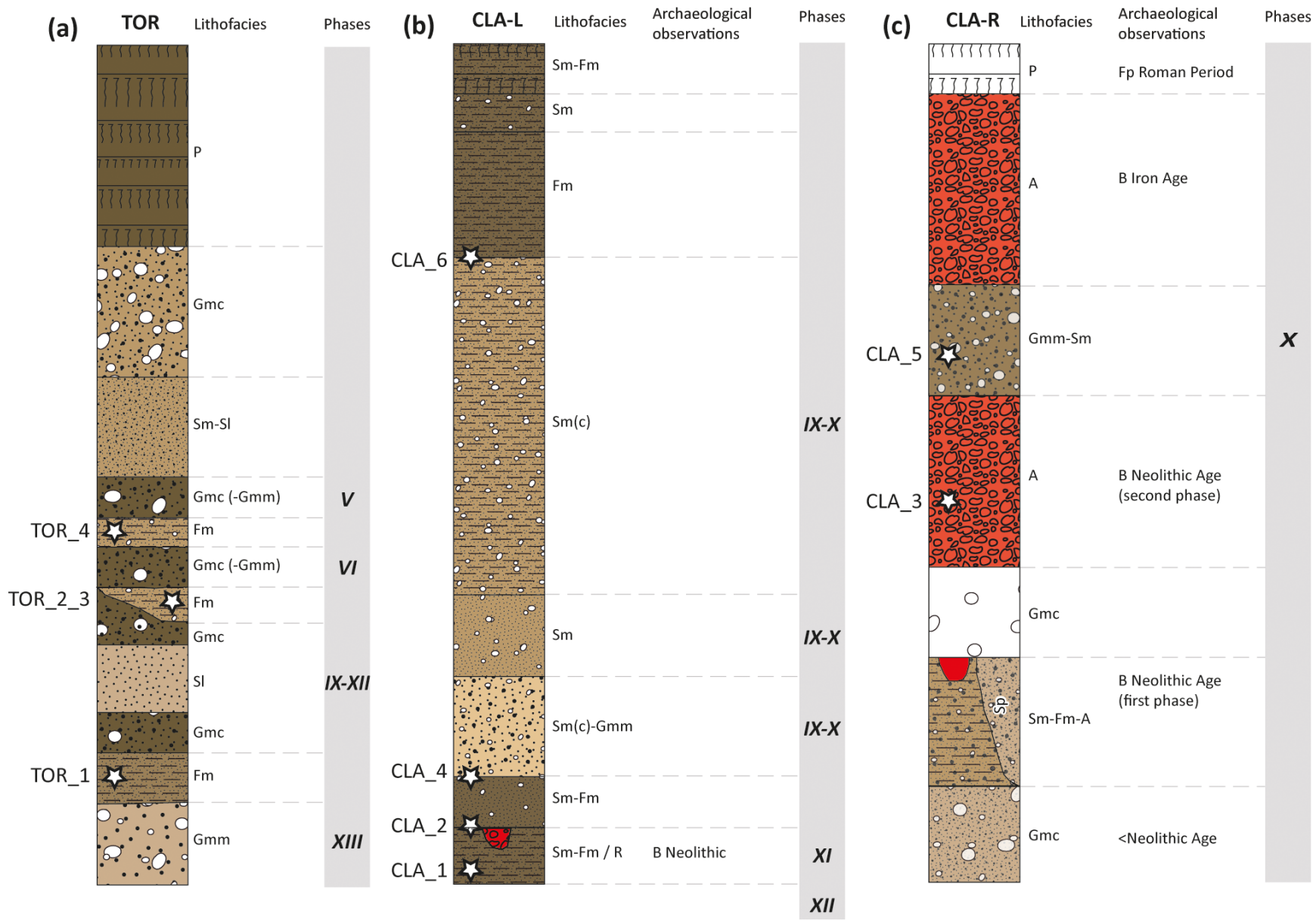

Figure 6. Stratigraphic logs in a timescale representation, with their corresponding lithofacies and archaeological remains. The phases (grey shaded) correspond to the enhanced hydro-sedimentary phases defined in Sect. 5.1. Sites: (a) Claro, Torrazza (TOR); (b) Claro, Longo (CLAL); (c) Claro, In Rasaréi (CLA-R). Codes for archaeological observations: B = backfilling; Fp = fragments of pottery.

consisting of layers of fine silty sand (Sm-Fm) and attributed to palaeosoils. Between the two units some remnants of anthropic structures, such as backfillings, were observed. Those were buried by the deposits of the second unit, which suggests a phase of intense alluvial activity affecting the settlements of the Neolithic Age. Afterwards three units of alluvial deposits of low to medium energy were described: the $\mathrm{Sm}$ (c)-Gmm unit which consists of a filling deposit of the fluvial channel and the overlaying poorly graded sands with gravel, $\mathrm{Sm}$ and $\mathrm{Sm}(\mathrm{c})$, which were probably formed by rapid decantation during the final part of the solid transport after depositing the coarser material. At the top of the sequence three units of fine sediments more or less rich in silt showed a partial or advanced pedogenesis (Fm, Sm or Sm-Fm).

Two phases of more intense alluvial activity described for CLA-L were constrained by radiocarbon dating on four charcoal samples (Fig. 6b and Table 3). A first phase during the Neolithic lasted until $2680 \mathrm{BCE}$ (lower limit of the interval of ages determined for CLA_2, Table 4), and subsequently a second phase must have occurred between 2340 BCE and
820 BCE (upper limit of ages for sample CLA_4 and lower limit of ages for sample CLA_6, Table 4).

In the case of CLA-R, the stratigraphic sequence shows eight different units, of which five are natural deposits and three are of anthropic origin (Fig. 6c), described as a first Neolithic phase, a second Neolithic phase and an Iron Age phase (Cardani Vergani, 2019, 2020, 2021). The bottom of the sequence consists of a coarse deposit attributed to an active fluvial band (Gmc), followed by a finer layer of a low-transport-energy fluvial deposit with some silt (Sm-Fm), which laterally varies in a planar crossbedded sandy deposit (Sp), and with evidence of trenches and backfillings attributed to the first Neolithic phase. Towards the top, a layer issued by a hyperconcentrated deposit $(\mathrm{Gmm})$ was observed. Between the two backfillings of Neolithic and Iron Age, an alluvial deposit unit classified as $\mathrm{Gmm}-\mathrm{Sm}$ was described and interpreted as a more intense alluvial activity phase. A unit characterised as actual soil was observed at the top of the stratigraphic sequence, but the findings of pottery fragments of the Roman Period indicate that it is actually older. 


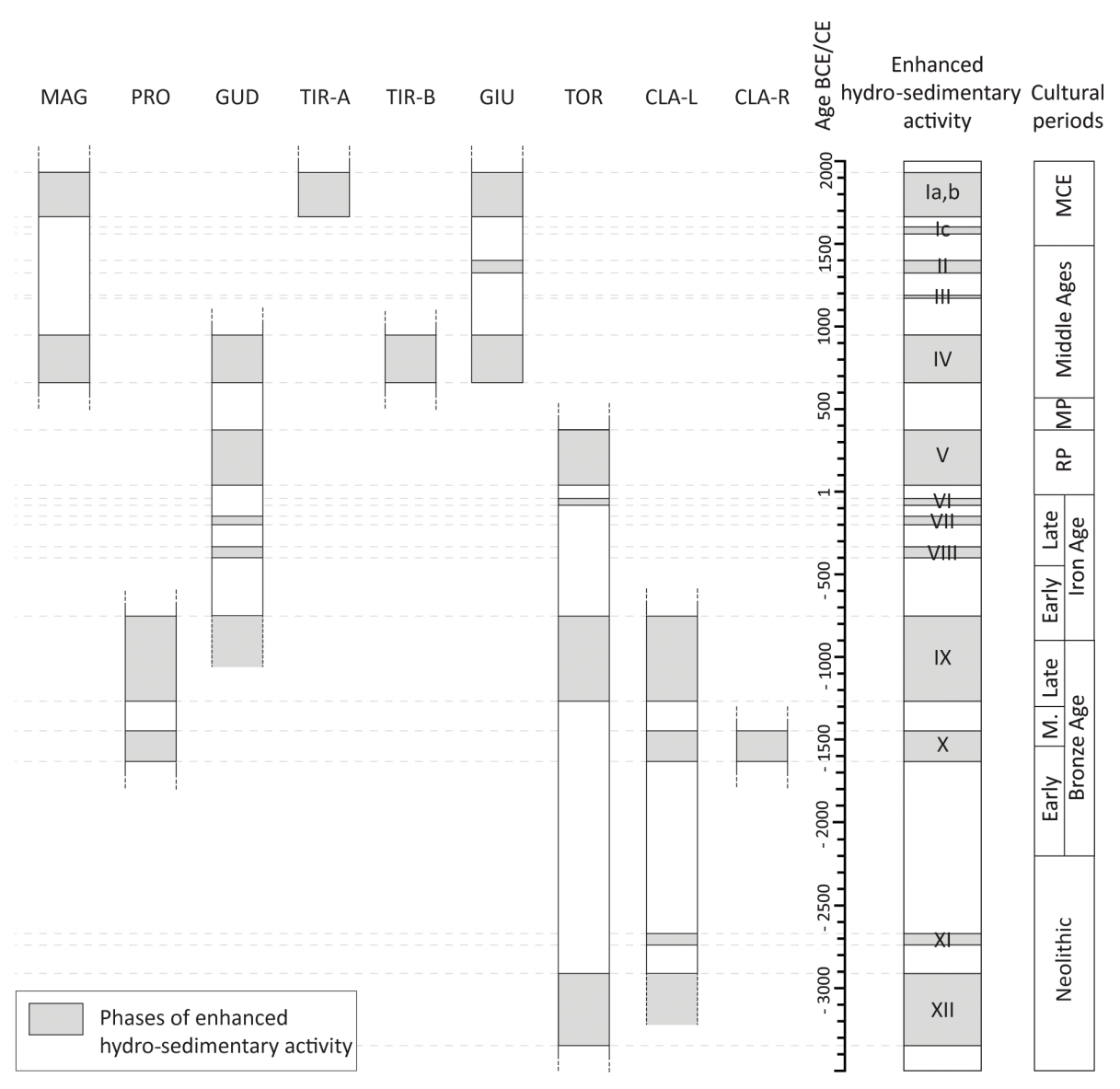

Figure 7. Synthetic representation of the enhanced hydro-sedimentary phases of the Ticino river based on the nine study sites in relation to the chronology of the cultural periods for the southern Swiss Alps. The sites are listed from the west to the east as presented in Fig. 1. The intervals of ages of each phase are shown in Table 5, and the cultural periods are described in Table 2.

In CLA-R two samples of charcoal were collected for radiocarbon dating (Fig. 6c and Table 3): the results for sample CLA_3 (2520 BCE, median calibrated age in Table 4) attribute it to the Neolithic Age, whereas the radiocarbon ages for sample CLA_5 constrain the enhanced hydrosedimentary activity phase observed between 1620 and 1450 BCE (Table 4), attributed to the Bronze Age. Both radiocarbon dating results are coherent with the archaeological observations.

\section{Discussion}

\subsection{Interpretation of the phases of enhanced hydro-sedimentary activity}

The joint analysis of the lithostratigraphy and archaeological evidence of anthropic artefacts and settlements allowed for the definition of 13 phases of enhanced hydro-sedimentary activity in the Ticino river and its tributaries since the $\mathrm{Ne}$ olithic (Table 5 and Fig. 7). Several phases were recognised in both the Ticino river and stream tributaries (phases Ia, Ib, Ic and IV), as well as other phases in more than one site (phases Ia, Ib, IV, V, IX, X and XII), whereas some phases were described only at one site (phases II, VI, VII, VIII, XI and XIII). Only phase III, related to the flood of $1178 \mathrm{CE}$, was defined exclusively from historical sources (Scapozza, 2013). Differences in age constraint through time allow us to define decadal to secular phases (phases I, II, VI, VII, VIII, $\mathrm{X}$ and $\mathrm{XI}$ ), such as longer multi-secular phases (phases IV, V, IX and XII). With the exception of the single event defined by phase III, the length of historic phases is between 35 (phase Ic) and 360 years (phase V), whereas for protohistoric and prehistoric phases it is between 30 (phases VII and VIII) and 520 years (phase IX).

Phases of the contemporary and modern periods, as well as of the Middle Ages, were defined thanks to the joint analysis of historical sources (Scapozza, 2013), fluvial deposit stratigraphy in the Ticino river floodplain (Scapozza and Oppizzi, 2013; Scapozza et al., 2017) and geoarchaeological observations carried out on the site of Giubiasco, Palasio (GIU). A period of intense fluvial activity during the second half of 17th century, the 18th and 19th centuries, and the first half of 20th century was recognised on the Ticino 
Table 5. Phases of enhanced hydro-sedimentary activity constrained with radiocarbon dating of samples of the present study, previous research and historical data. For the precise interval of ages corresponding to the source sample, see Table 4. For the detailed chronology for the cultural periods, see Table 2 .

\begin{tabular}{|c|c|c|c|c|}
\hline Phases & Cultural period & $\begin{array}{l}\text { Start of } \\
\text { the phase } \\
\text { (BCE/CE) }\end{array}$ & $\begin{array}{r}\text { End of } \\
\text { the phase } \\
(\mathrm{BCE} / \mathrm{CE})\end{array}$ & Source \\
\hline Ia & Contemporary period & 1868 & 1930 & Scapozza (2013) \\
\hline $\mathrm{Ib}$ & Modern and contemporary periods & 1777 & 1840 & Scapozza (2013) \\
\hline $\mathrm{Ia}, \mathrm{b}$ & Modern and contemporary periods & 1680 & 1930 & TIR_3 \\
\hline $\mathrm{Ia}, \mathrm{b}$ & Modern and contemporary periods & 1690 & 1920 & MAG_3 \\
\hline $\mathrm{Ia}, \mathrm{b}$ & Modern and contemporary periods & 1660 & 1820 & GIU_5, archeological interpretation \\
\hline Ic & Modern period & 1566 & 1601 & Scapozza $(2013)$ \\
\hline II & Late Middle Ages & 1320 & 1400 & GIU_2, GIU_3 \\
\hline III & High Middle Ages & 1178 & 1178 & Scapozza (2013), Scapozza and Oppizzi (2013) \\
\hline IV & Early Middle Ages/High Middle Ages & 6 th and 7 th centuries & $<1170$ & Archaeological interpretation, GIU_1 \\
\hline IV & Early Middle Ages & 680 & 960 & MAG_2, MAG_1 \\
\hline IV & Early Middle Ages & $680-890$ & & TIR_1 \\
\hline IV & & $>550$ & & GUD_5 \\
\hline $\mathrm{V}$ & & $<120$ & & TOR_4 \\
\hline $\mathrm{V}$ & Roman Period & 20 & 380 & GUD_4, GUD_5 \\
\hline VI & & & $<-60$ & TOR_4 \\
\hline VII & La Tène C (Late Iron Age) & -200 & -170 & GUD_2,GUD_4 \\
\hline VIII & La Tène B (Late Iron Age) & -400 & -370 & GUD_1, GUD_3 \\
\hline IX & & $>-800$ & & TOR_2, TOR_3 \\
\hline IX & & & $<-910$ & TOR_2, TOR_3 \\
\hline IX & Late Bronze Age/Early Iron Age & -1280 & -760 & PRO_1, GUD_1 \\
\hline $\mathrm{X}$ & Middle Bronze Age & -1620 & -1450 & CLA_5,PRO_1 \\
\hline $\mathrm{IX}-\mathrm{X}$ & & -2340 & -820 & CLA_4, CLA_6 \\
\hline $\mathrm{XI}$ & Neolithic & -2750 & -2680 & CLA_1, CLA_2 \\
\hline XII & Neolithic & -3360 & -2920 & TOR_1, CLA_1 \\
\hline XIII & Neolithic & & $<-3530$ & TOR_1 \\
\hline
\end{tabular}

river delta between 1690 and 1920 CE (MAG_3), on the Ticino river floodplain between 1680 and 1930CE (TIR_3), and in the stream of Giubiasco, Palasio, between 1660 and 1820 CE (GIU_5 and archaeological evidence). Evidence for phase IV occurring during the Early Middle Ages was also found in several locations. On the Ticino river delta, this phase was dated between 680 and 960CE (MAG_1 and MAG_2), whereas observations collected on the floodplain have provided a dating after 680-890 CE (TIR_1). Partial evidence from Gudo indicates a beginning of this phase after 550 CE (GUD_5), whereas archaeological attribution of a building and radiocarbon dating of GIU_1 from Giubiasco, Palasio, indicate a phase of activity of tributary streams that began during the 6th/7th century $\mathrm{CE}$ and ended before $1170 \mathrm{CE}$.
For the Roman Period, the Iron Age and the Bronze Age, the six phases of enhanced hydro-sedimentary activity (one during the Roman Period, three during the Iron Age and two during the Bronze Age) were defined thanks to complementary evidence from the two sites of Claro (CLA-R and TOR) and the two sites of Gudo (GUD and PRO). For phase IX, the starting and ending dates (1280 and $760 \mathrm{BCE})$ were defined clearly thanks to the complementary stratigraphy of the two sites of Gudo (dating PRO_1 and GUD_1). A coherent result was defined thanks to observations from Claro, Torrazza, where an antecedent phase was defined as ending before $910 \mathrm{BCE}$, and a subsequent phase was defined as beginning after $800 \mathrm{BCE}$ (TOR_2 and TOR_3). Phase X occurred during the Early and Middle Bronze Age and was defined thanks to a hyperconcentrated deposit dated between 1620 and 1490 BCE in Claro (CLA_5) and was 
also recognised, with similar sedimentological evidence, in Gudo, Progero (PRO_1). The three phases of the Neolithic were finally defined thanks to the three sites investigated in Claro (CLA-L, CLA-R and TOR), for which lithostratigraphical complementarity allowed us to define phase XII according to the terminus post quem (3360 BCE) defined by TOR_1 and the terminus ante quem (2920 BCE) defined by CLA_1.

\subsection{Palaeoenvironmental and palaeoclimatic causes of the enhanced hydro-sedimentary activity phases}

\subsubsection{Neolithic and Early Bronze Age (5500-1550 BCE)}

Phase XIII ( $>3530$ BCE) occurred before and during the beginning of the Piora II cold climate oscillation (ca. 3550$3000 \mathrm{BCE}$ according to a new calibration of period dating from Burga et al., 2001), whereas phase XII (33602920 BCE) occurred during/just after this climate oscillation. Considering also phase XI (2750-2680 BCE), the three enhanced hydro-sedimentary activity phases evidenced during the Neolithic occurred during periods of general glacier recession in the Swiss Alps, which were dated between 37103540 and 3340-1920 BCE (Hormes et al., 2006) and 37503550 and 3250-2450 BCE (Joerin et al., 2006). These three phases also correspond to minor peaks of flood activity on the southern side of the Alps, defined thanks to the analysis and dating of lacustrine sediments in southern Switzerland and northern Italy (Wirth et al., 2013). Phase XII ended in agreement with the lowest residual $\Delta^{14} \mathrm{C}$ values recorded between 3000 and 450 BCE (Fig. 8), with the negative peak (minimal value of $-10.6 \%$ in $2935 \mathrm{BCE}$ ) indicating high solar activity. On the contrary, the period between phases XII and XI was characterised by very low solar activity, as indicated by the positive peak presenting the highest maximal value $(+16.1 \%$ in $2825 \mathrm{BCE})$ of the last 5000 years (Fig. 8). No evidence of enhanced river activity was observed for more than a millennium between 2680 and 1620 BCE even if in Claro a long sequence of coarse fluvial sediments, assuming several phases of hydro-sedimentary activity, was dated between 2340 BCE (CLA_4) and 820 BCE (CLA_6) (Table 5). Those phases correspond to the period of enhanced rainfall evidenced by Wirth et al. (2013) between 2250 and 450 BCE (Fig. 8).

Palynological evidence from the peat bog of Guér, located above Claro (coord. CH1903+/LV95: 2722 050/1 126500; $835 \mathrm{~m}$ a.s.1.), indicates a progressive increase in the anthropic pressure on the territory during the Neolithic, supported by the numerous archaeological investigations carried out in Claro and neighbouring localities (Morales-Molino et al., 2015; Carlevaro et al., 2017). Cultural indicators (CIs; sum of Cerealia-type and Plantago-lanceolata-type pollen; Tinner et al., 2003) and microscopic charcoal concentration indicate an increase in anthropic pressure between 3300 and 2600 BCE (Morales-Molino et al., 2015), which reached a peak between 2500 and $1850 \mathrm{BCE}$ as indicated also by the maximum values of fire frequency episodes of the Neolithic and Early Bronze Age (Fig. 8).

\subsubsection{Middle and Late Bronze Age and Iron Age (1550-15 BCE)}

Phases X (1620-1490 BCE) and IX (1280-760 BCE) occurred during the period of enhanced rainfall of the beginning of the Meghalayan Stage/Age (Fig. 8). Phase X, in particular, occurred during a cold and moist climate phase (1650-1450 BCE; Tinner et al., 2003) of the Löbben cold climate oscillation (ca. 1800-1350 BCE; Burga et al., 2001), which characterised the transition from the Early to the Middle Bronze Age (Fig. 8). Phase IX, on the contrary, corresponds almost entirely with the warm and dry climate of the Bronze Warm Period (ca. 1350-950 BCE), which was intercalated between the Löbben and Göschenen I cold climate oscillations (Burga et al., 2001).

The period of enhanced rainfall ending in the Early Iron Age was characterised, around $550 \mathrm{BCE}$, by the highest flood activity recorded in the southern Alps for the entire Holocene (Wirth et al., 2013; Fig. 8). This peak was synchronous with the maximum Grosser Aletschgletcher (Great Aletsch Glacier) advance of 1000-600 BCE (Holzhauser et al., 2005) corresponding to the Göschenen I cold climate oscillation (ca. 950-300 BCE; Burga et al., 2001). After the intense rainfall period, three well-constrained enhanced hydro-sedimentary phases were defined during the Late Iron Age. Phase VIII (400-370 BCE) occurred after the lowest peak in residual $\Delta^{14} \mathrm{C}$ values (minimal value of $-11.7 \%$ in $420 \mathrm{BCE}$ ) ever recorded between $3000 \mathrm{BCE}$ and $1100 \mathrm{CE}$. Phase VII (200-170 BCE), corresponding to a secondary peak of the flood activity on the southern side of the Alps, occurred during a cold and moist climate phase (225-175 BCE; Tinner et al., 2003) at the beginning of the Roman Warm Period (300 BCE-400 CE; Patterson et al., 2010). Together with phase VI (ending before $60 \mathrm{BCE}$ but whose beginning was not determined), they occurred during the generalised glacier retreat period of the Roman Warm Period, dated between $350 \mathrm{BCE}$ and $780 \mathrm{CE}$ (Hormes et al., 2006) and between $200 \mathrm{BCE}$ and $100 \mathrm{CE}$ (Joerin et al., 2006).

The period between phases IX and VII was characterised, on the lower part of the slopes of the Ticino Valley, by a significant intensification of land use during the Early Iron Age and the beginning of Late Iron Age (Tinner et al., 2003; Morales-Molino et al., 2015; Carlevaro et al., 2017). Evidence from the Guér peat bog indicates a peak of microscopic charcoal concentration around $650 \mathrm{BCE}$, with the maximum frequency of fire episodes (more than eight episodes per thousand years; see Fig. 8) registered between 900 and 300 BCE. Pollen used as CIs presented, during this period, a maximum peak around $800 \mathrm{BCE}$ for the Plantago lanceolata type and around $300 \mathrm{BCE}$ for the Cerealia type (MoralesMolino et al., 2015). The link between indicators for fire episodes and CI, as well as the presence of several archae- 


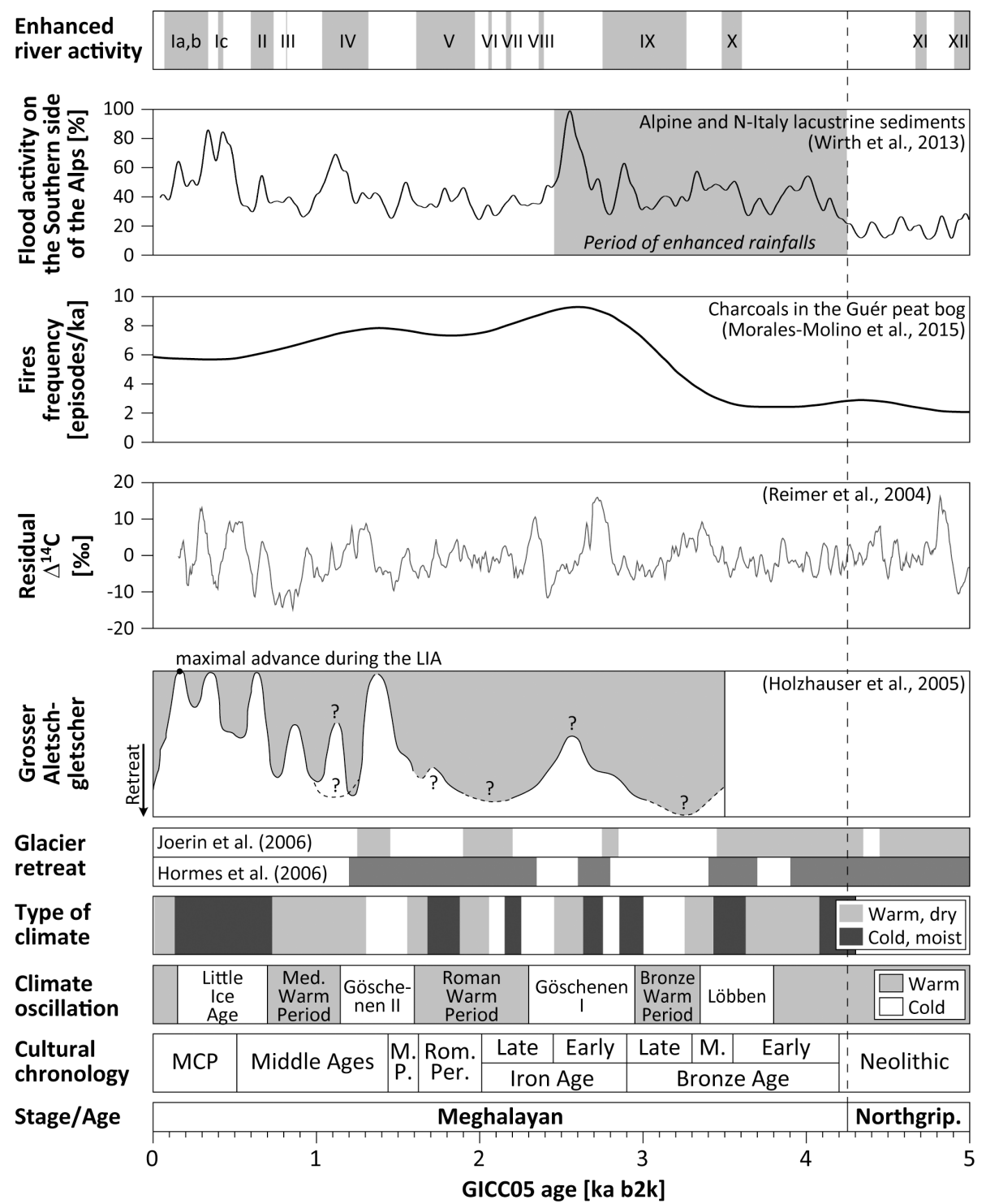

Figure 8. Enhanced river activity phases defined in this study, compared with the main morphoclimatic indicators defined for the central and southern Swiss Alps during the Meghalayan Stage/Age (Upper/Late Holocene subseries/subepoch) compiled by Scapozza (2019). Sources: type of climate from Tinner et al. (2003) for the period between $2300 \mathrm{BCE}$ and $800 \mathrm{CE}$, from Mann et al. (2009) for the Medieval Warm Period, and from Zumbühl and Holzhauser (1988) for the Little Ice Age; climate oscillations from Burga et al. (2001), as well as from Patterson et al. (2010) for the Roman Warm Period; cultural chronology from Table 3. Abbreviations: GICC05= Greenland Ice Core Chronology 2005; LIA = Little Ice Age; M. = middle; MCP = modern and contemporary period; M. P. = Migration Period; Northgrip. $=$ Northgrippian; Rom. Per. $=$ Roman Period.

ological sites in Claro and neighbouring localities during the Bronze Age and the Iron Age, indicates significant humancontrolled fire activity during this period (Morales-Molino et al., 2015; Carlevaro et al., 2017). Despite the reduced forest cover and the period of climatic degradation corresponding to Göschenen I oscillations, less evidence for enhanced hydro-sedimentary activity can be obtained from archaeological sites. As highlighted by the L-shaped wall discovered in Gudo, erected in the period 370 and 200 BCE between phases VIII and VII of enhanced hydro-sedimentary activity, it is probably during the Iron Age that there was a stabilisation of human settlements which led to the need to build dams to contain water coming from the valley bottom river and/or from streams on the slope (Scapozza and Czerski, 2019).

\subsubsection{Roman Period and Middle Ages (15 BCE-1492 CE)}

Phase V (20-380 CE) occurred during the Roman Period corresponding to the cold and moist climate phase of 150 


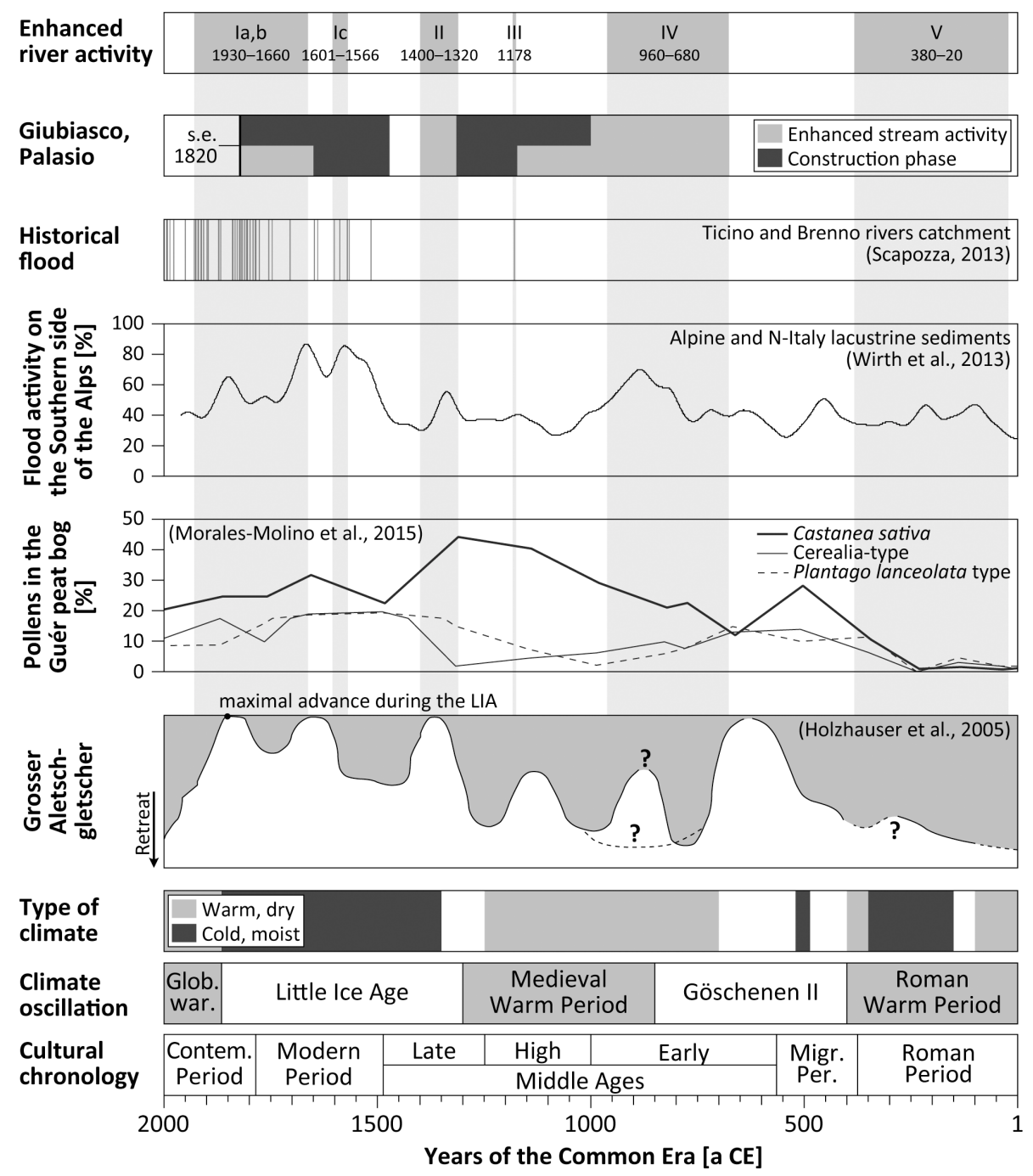

Figure 9. Enhanced river activity phases and construction phases for Giubiasco, Palasio (GIU), defined in the study, compared with the main morphoclimatic indicators defined for the central and southern Swiss Alps during the common era. Sources: see Fig. 8. Abbreviations: Contem. $=$ contemporary; Glob. war. = global warming; LIA = Little Ice Age; Migr. Per. = Migration Period; s. e. $=$ stream embankment.

350 CE (Tinner et al., 2003), placed in the Roman Warm Period (Fig. 9). Phase IV (680-960 CE), occurred between the Göschenen II cold climate oscillation (400-850 CE; Burga et al., 2001) and the Medieval Warm Period (850-1300 CE; Mann et al., 2009), mainly corresponding to the warm and dry climate phase of 700-1250 CE (Tinner et al., 2003; Mann et al., 2009). Within this phase is placed the peak of flood activity culminating around 900 CE (Wirth et al., 2013; Fig. 9). The period between phases V and IV (380-680 CE) was marked by the first peak in Castanea sativa pollen in $510 \mathrm{CE}$ after the introduction and cultivation of this tree species around 150 CE (Morales-Molino et al., 2015). Frequency of fire episodes, after a second-order minimum in the first centuries of the common era, presents the second highest peak (just below eight episodes per thousand years; see Fig. 8) between 400 and $800 \mathrm{CE}$, indicating an increased anthropic pressure during the Migration Period and the Early Middle Ages (Morales-Molino et al., 2015).

Phase V, which was defined thanks to evidence from valley side streams in Claro, Torrazza (TOR_4), and Gudo (GUD_4 and GUD_5; Table 5), has not been recognised in the Ticino river, which rather presented a particularly calm period of hydro-sedimentary activity during the Roman Period and the Migration Period (Scapozza and Oppizzi, 2013). Phase IV, on the contrary, perfectly corresponds to the period of enhanced hydro-sedimentary activity evidenced both on the Ticino river floodplain (Scapozza and Oppizzi, 2013; Scapozza et al., 2017) and in the valley side streams of Giubiasco and Gudo. The multiplication of evidence for this phase indicated that it was generalised on the southern side of the Alps. It was also recognised in the French Upper Rhone catchment (Haut Rhône) where, after repeated heavy rain episodes be- 
tween $100 \mathrm{BCE}$ and $100 \mathrm{CE}$, followed by rare flood events between 100 and $250 \mathrm{CE}$ and a relatively dry period between 250 and 500 CE (Bravard et al., 1992; Arnaud et al., 2005), the three centuries between 500 and $800 \mathrm{CE}$ were marked by a phase of moderate torrential activity and by a significant resumption of river activity (Arnaud-Fassetta and Landuré, 2003; Arnaud et al., 2005; Salvador et al., 2005).

Phase III (1178 CE) occurred during the Medieval Warm Period after almost two centuries of low hydrological activity and, as already mentioned in Sect. 5.1, was defined only on the basis of historical information (Scapozza, 2013). Based on a single flood episode, this phase cannot be correlated with a specific phase of enhanced hydro-sedimentary activity. Considering that on the French Upper Rhone the main phases are probably slightly older than on the Ticino river (Scapozza and Oppizzi, 2013), this period of low activity corresponds with the phase of deficient hydrology of $800-1000 \mathrm{CE}$ and/or the phase of rare erosive events of 1000-1100 CE (with the lowest hydrological index of 0 and 1, respectively, on a scale of 5) defined by Bravard et al. (1992) and affirmed by Arnaud et al. (2005). Flood events were recognised on the Upper Rhone River between 1050 and $1250 \mathrm{CE}$ (Bravard et al., 1992; Arnaud et al., 2005), indicating that the $1178 \mathrm{CE}$ flood on the Ticino river may not have been the only one in that period. Between phases IV and III, in Giubiasco the first Medieval phase of construction (11th-12th centuries) was identified, ending before $1170 \mathrm{CE}$ (GIU_1, Table 4). A second construction phase was identified between 1170 and $1320 \mathrm{CE}$, i.e. before phase II of enhanced hydrological activity, dated between 1320 and 1400 CE (GIU_2 and GIU_3), which destroyed the building erected during the first two Medieval construction phases.

Phase II (1320-1400 CE) presents a very good correspondence with the period of increased flood activity on the southern side of the Alps evidenced between 1300 and $1400 \mathrm{CE}$ (Wirth et al., 2013; Fig. 9) and corresponding to the first phase of the Little Ice Age, which is characterised by glacier advance between 1300 and 1350 CE (Holzhauser et al., 2005). This phase occurred just after the peak of Castanea sativa pollen recorded in Guér, above Claro, around $1300 \mathrm{CE}$ (Fig. 9), belonging to the second maximum of sweet chestnut of 1150-1450 CE caused by its flourishing use for staple food production and characterised by the highest pollen concentrations since the chestnut introduction in $150 \mathrm{CE}$ (MoralesMolino et al., 2015).

\subsubsection{Modern and contemporary periods (1492 CE-today)}

Phase I corresponds with the generalised hydro-sedimentary rupture characterising the period between the 16th and 19 th centuries which is related to the coldest phases of the Little Ice Age (Pfister, 1984; Zumbühl and Holzhauser, 1988; Scapozza, 2014) and defined as a "major torrential crisis" in the French Upper Rhone River, with a hydrological index of $5 / 5$ between 1350 and $1800 \mathrm{CE}$ (Bravard et al., 1992; Arnaud et al., 2005). Considering the historical flood events compiled for the Swiss Ticino river catchment, with 38 flood events identified between 1566 and $1930 \mathrm{CE}$ (Scapozza, 2013:81; Fig. 9), phase I can be divided into three sub-phases of major flood frequency ( $>10$ events per $100 \mathrm{a})$ : phase Ic, with 5 floods between 1566 and $1601 \mathrm{CE}$ (14 events per $100 \mathrm{a}$ ); phase Ib, with 16 floods between 1777 and $1840 \mathrm{CE}$ (25 events per $100 \mathrm{a}$ ), and phase Ia, with 12 floods between 1868 and 1930 CE (19 events per $100 \mathrm{a}$ ). Considering also the field evidence for these phases of major river activity, coming from the Ticino river delta (MAG_3 in Table 4; Scapozza and Oppizzi, 2013), the Ticino river floodplain (TIR_3; Scapozza et al., 2017) and the site of Giubiasco (GIU_3), phases Ia and Ib were grouped and cover the period between 1660 and 1930 CE (Table 5). Especially in Giubiasco, the structures built during construction phase 3 (corresponding to the 1470-1640 CE period of hydro-sedimentary calm) were destroyed between 1660 and $1790 \mathrm{CE}$. The enhanced torrential activity ended only in $1820 \mathrm{CE}$ following the embankment of the stream.

\section{Conclusion}

Three main conclusions can be drawn from the lithostratigraphical observations and the geochronological assessments thanks to radiocarbon dating and archaeological interpretations at the study sites:

1. The combined approach allowed us to determine 13 phases of enhanced hydro-sedimentary activity of the Ticino river and its tributaries since the Neolithic. The three phases of the Neolithic (XIII, XII, XI) were defined thanks to the three sites investigated in Claro (CLA-L, CLA-R and TOR). The phases for the Bronze Age (X, IX), the Iron Age (IX, VIII and VII) and the Roman Period (V) were defined thanks to complementary evidence both from the two sites of Claro (CLA-R and TOR) and from the two sites of Gudo (GUD and PRO). Phases of the Middle Ages (IV, III and II), as well as of the modern and contemporary periods (Ic, Ia, b, Ib and Ia), were defined thanks to the joint analysis of historical sources, fluvial deposit stratigraphy in the Ticino river floodplain and geoarchaeological observations carried out on the site of Giubiasco, Palasio (GIU).

2. The phases of enhanced hydro-sedimentary activity could be linked to regional or continental palaeoenvironmental and palaeoclimatic causes. In fact, most of them were observed in concurrence with periods of climate degradation with the establishment of cold and humid conditions, supported by data of glacier fluctuations in the Swiss Alps and/or by the increase in flood activity on the southern side of the Alps. Among these 
phases are included the phase $\mathrm{X}$ of the Middle Bronze Age, phase IX of the Late Bronze Age/Early Iron Age, phases VIII and VII of the Late Iron Age, phase V of the Roman Period, phase IV of the Early Middle Ages and all the events related to phases II and I that occurred between the Late Middle Ages and the contemporary period. Phases II and I in particular are related to the last cold climate oscillation of the Little Ice Age.

3. The collected data allowed us to assess the impacts of these increased alluvial phases on the human communities and to confirm some of the sedimentological and archaeological observations from the field. In the archaeological site of Gudo (GUD), for example, the construction of an L-shaped wall, erected in the period 370-200 BCE between phases VIII and VII of enhanced hydro-sedimentary activity, proved the need to build dams to contain water coming from the valley bottom river and/or from streams on the slope. Also in Giubiasco, Palasio (GIU), the torrential events attributed to the Little Ice Age climate oscillation had a strong impact on the construction and destruction phases observed.

All the results confirmed the validity of the combined approach applied in this study. In the future, the overview on the evolution of the morphosedimentary dynamics of the Ticino river and its tributaries presented herein will be continuously refined and updated with further sedimentological and archaeological observations.

Data availability. All the relevant results of the geoarchaeological observations and dating are presented in the article.

Author contributions. CS, DC and DG performed the investigation, formal analysis and preparation of the manuscript in equal parts.

Competing interests. Cristian Scapozza is one of the two associate editors for the theme issue "Geomorphology and society". The peer-review process was guided by an independent editor, and the authors also have no other competing interests to declare.

Disclaimer. Publisher's note: Copernicus Publications remains neutral with regard to jurisdictional claims in published maps and institutional affiliations.

Acknowledgements. The authors would like to thank the Section of Archaeology, Ufficio dei Beni Culturali of Canton Ticino, for the collaboration during the last years. Particular thanks to Rossana Cardani Vergani, Luisa Mosetti, Michele Pellegrini, Maruska Federici-Schenardi, Mattia Gillioz, Giorgio Nogara and
Gabriele Giozza for sharing their data from archaeological inspections and for the fruitful exchange of information.

Review statement. This paper was edited by Nikolaus J. Kuhn and reviewed by three anonymous referees.

\section{References}

Académies suisses des sciences: Coup de projecteur sur le climat suisse, Etat des lieux et perspectives, swiss academies reports, $11 / 5$, p. 218 , available at: https://proclim.scnat.ch/fr/activities/ brennpunkt/downloads (last access: 21 December 2021), 2016.

Arnaud, F., Revel, M., Chapron, E., Desmet, M., and Tribovillard, N.: 7200 years of Rhône river flooding activity in Lake Le Bourget, France: a high-resolution sediment record of NW Alps hydrology, Holocene, 15, 420-428, https://doi.org/10.1191/0959683605hl801rp, 2005.

Arnaud-Fassetta, G., and Landuré, C.: Hydroclimatic hazards, vulnerability of societies and fluvial risk in the Rhône Delta (Mediterranean France) from the Greek period to the Early Middle Ages, in: The Mediterranean World Environment and History, Proceedings of the International Conference "Environmental Dynamics and History in Mediterranean Areas" held in Paris, 24-26 April 2002, edited by: Fouache E., Elsevier, Paris, France, 51-76, 2003.

Bravard, J. P. and Petts, G. E.: Human impacts on fluvial systems, in: Fluvial hydrosystems, edited by: Petts, G. E. and Amoros, C., Chapman \& Hall, London, UK, 233-256, 1996.

Bravard, J.-P., Verot-Bourrely, A., and Salvador, P.-G.: Le climat d'après les informations fournies par les enregistrements sédimentaires fluviatiles étudiées sur des sites archéologiques, Les nouvelles de l'Archéologie, 50, 7-14, 1992.

Bronk Ramsey, C.: Development of the Radiocarbon Program OxCal, Radiocarbon, 43, 355-363, https://doi.org/10.1017/S0033822200038212, 2001.

Bronk Ramsey, C.: OxCal 4.4 Manual, Radiocarbon Accelerator Unit, Oxford, United Kingdom, available at: https://c14.arch.ox. ac.uk/oxcal/OxCal.html (last access: 21 December 2021), 2020.

Burga, C., Perret, R., and Zoller, H.: Swiss localities of early recognized Holocene climate oscillations - characterisation and significance, Vier. Natur. Gesell. Zürich, 146, 65-74, 2001.

Cailleux, A. and Tricart, J.: Initiation à l'étude des sables et des galets, 3 vol., Centre de Documentation Universitaire, Paris, France, 1963.

Cardani Vergani, R.: Ricerche archeologiche in Cantone Ticino nel 2017, Boll. Ass. Archeol. Ticin., 30, 30-37, https://doi.org/10.5169/seals-737980, 2018.

Cardani Vergani, R.: Ricerche archeologiche in Cantone Ticino nel 2018, Boll. Ass. Archeol. Ticin., 31, 21-35, 2019.

Cardani Vergani, R.: Ricerche archeologiche in Cantone Ticino nel 2019, Boll. Ass. Archeol. Ticin., 32, 26-33, 2020.

Cardani Vergani, R.: Ricerche archeologiche in Cantone Ticino nel 2020, Boll. Ass. Archeol. Ticin., 33, 24-31, 2021.

Carlevaro, E.: Dinamiche del popolamento nell'area sudalpina dal Bronzo finale alla romanizzazione, Università di Zurigo, Zurigo, Svizzera, 343 pp., available at: https://zora.uzh.ch/id/ eprint/164250/ (last access: 21 December 2021), 2013. 
Carlevaro, E., Colombaroli, D., Conedera, M., Krebs, P., MoralesMolino, C., Scapozza, C., Tinner, W., and Vescovi, E.: Claro e il suo territorio, Archeol. Schweiz, 40, 24-29, https://doi.org/10.5169/seals-768568, 2017.

Conedera, M. and Tinner, W.: Ferro e fuoco: una ricostruzione paleoecologica dell'approccio territoriale nella Regione Insubrica in età preistorica, in: I Leponti, tra mito e realtà, edited by: de Marinis, R. C. and Biaggio Simona, S., Armando Dadò, Locarno, Svizzera, 63-70, 2000.

Crivelli, A.: Atlante preistorico e storico della Svizzera italiana, Ristampa anastatica dell'edizione del 1943 e aggiornamento a cura di P. A. Donati, Casagrande, Bellinzona, Svizzera, p. 156, 1990.

De Marinis, R. C. and Biaggio Simona, S.: I Leponti, tra mito e realtà, 2 vol., Armando Dadò, Locarno, Svizzera, 419+ 489 pp., 2000.

Documentazione IVS Cantone Ticino: Percorso TI 1.2.3: Strada francesca (sponda sinistra), Bellinzona/Ravecchia - Giubiasco, Inventario delle vie di comunicazione storiche della Svizzera (IVS)m Bern, Schweiz, p. 2, 1999.

Donati, P.: Bellinzona a Castel Grande: 6000 anni di storia, Archeol. Schweiz, 9, 94-109, https://doi.org/10.5169/seals-8233, 1986.

Glaser, R., Ammann, B., Brauer, A., Heiri, O., Jacobeit, J., Lotter, A. F., Luterbacher, J., Maisch, M., Magny, M., Pfister, C., Tinner, W., Veit, H., and Wanner, H.: Palaeoclimate within the River Rhine Catchment during Holocene and Historic Times, Erdkunde, 59, 251-275, 2005.

Grant, J., Gorin, S., and Fleming, N.: The archaeology coursebook: an introduction to study skills, topics and methods, Routledge, London, UK, p. 692, 2015.

Grossi, P.: Vita di un fiume. Consorzio correzione fiume Ticino dalla Moesa al Lago Maggiore 1886-1986, Salvioni, Bellinzona, Svizzera, 395 pp., 1986.

Holzhauser, H., Magny, M., and Zumbühl, H. J.: Glacier and lake-level variations in west-central Europe over the last 3500 years, Holocene, 16, 789-801, https://doi.org/10.1191/0959683605hl853ra, 2005.

Hormes, A., Beer, J., and Schlüchter, C.: A geochronological approach to understanding the role of solar activity on Holocene glacier length variability in the Swiss Alps, Geogr. Ann. A, 88, 282-294, https://doi.org/10.1111/j.0435-3676.2006.00301.x, 2006.

James, L. A. and Marcus, W. A.: The human role in changing fluvial systems: Retrospect, inventory and prospect, Geomorphology, 79, 152-171, https://doi.org/10.1016/j.geomorph.2006.06.017, 2006.

Joerin, U. E., Stocker, T. F., and Schlüchter, C.: Multicentury glacier fluctuations in the Swiss Alps during the Holocene, Holocene, 16, 697-704, https://doi.org/10.1191/0959683606hl964rp, 2006.

King, C. A.: Techniques in geomorphology, Arnold, London, UK, p. 342, 1966.

Laigre, L., Reynard, E., Arnaud-Fassetta, G., Baron, L., and Glenz, D.: Caractérisation de la paléodynamique du Rhône en amont de Martigny (Valais, Suisse) à l'aide de la tomographie de résistivité électrique (TRE), Géomorphologie, 4, 405-426, https://doi.org/10.4000/geomorphologie.10020, 2012.

Mann, M. E., Zhang, Z., Rutherford, S., Bradley R. S., Hughes, M. K., Shindell, D., Ammann, C., Faluvegi, G., and Fenbiao, N.: Global signatures and dynamical origins of the Little Ice
Age and Medieval Climate Anomaly, Science, 326, 1256-1260, https://doi.org/10.1126/science.1177303, 2009.

Martinoli, G.: La correzione del fiume Ticino dal riale di Sementina al Lago Maggiore, Benzinger \& Co., Einsiedeln, Svizzera, p. 63, 1896.

Miall, A. D.: A review of the braided river depositional environments, Earth Sci. Rev., 13, 1-62, https://doi.org/10.1016/00128252(77)90055-1, 1977a.

Miall, A. D.: Lithofacies types and vertical profile models in braided river deposits: a summary, in: Fluvial Sedimentology, edited by: Miall, A. D., Geological Survey of Canada, Calgary, Canada, 597-604, 1977b.

Minor, H.-E., Hager, W. H., Filippini, L., Pellandini, S., and GheriPusch, A.: Ingegneria fluviale in Svizzera: sviluppo e prospettive, Società dell'arte e dell'ingegneria civile, Zurigo, Svizzera, p. 140, 2004.

Morales-Molino, C., Vescovi, E., Krebs, P., Carlevaro, E., Kaltenrieder, P., Conedera, M., Tinner, W., and Colombaroli D.: The role of human-induced fire and sweet chestnut (Castanea sativa Mill.) cultivation on the long-term landscape dynamics of the Southern Swiss Alps, Holocene, 25, 482-494, https://doi.org/10.1177/0959683614561884, 2015.

Moscato, S. (Ed.): Treccani 2000 Il mondo dell'archeologia, Vol. 1, Istituto della Enciclopedia Italiana, Roma, Italia, p. 1906, 2002.

Patterson, W. P., Dietrich, K. A., Holmden, C., and Andrews, J. T.: Two Millennia of North Atlantic seasonality and implications for Norse colonies, P. Natl. Acad. Sci. USA, 107, 5306-5310, https://doi.org/10.1073/pnas.0902522107, 2010.

Pfister, C.: Klimageschichte der Schweiz 1525-1860. Das Klima der Schweiz von 1525-1860 und seine Bedeutung in der Geschichte von Bevölkerung und Landwirtschaft, 2 Bd., Haupt, Bern, Schweiz, $245+174$ pp., 1984.

Piffaretti, P. and Luchessa, C.: Lo scorrere del fiume, l'opera dell'uomo. 125 anni di attività del Consorzio Correzione Fiume Ticino (1886-2011), Salvioni, Bellinzona, Svizzera, 164 pp., 2011.

Reimer, P. J., Austin, W. E. N., Bard, E., Bayliss, A., Blackwell, P. G., Bronk Ramsey, C., Butzin, M., Cheng, H., Edwards, R. L., Friedrich, M., Grootes, P. M., Guilderson, T. P., Hajdas, I., Heaton, T. J., Hogg, A. G., Hughen, K. A., Kromer, B., Manning, S. W., Muscheler, R., Palmer, J. G., Pearson, C., van der Plicht, J., Reimer, R. W., Richards, D. A., Scott, E. M., Southon, J. R., Turney, C. S., Wacker, L., Adolphi, F., Büntgen, U., Capano, M., Fahrni, S. M., Fogtmann-Schulz, A., Friedrich, R., Köhler, P., Kudsk, S., Miyake, F., Olsen, J., Reinig, F., Sakamoto, M., Sookdeo, A., and Talamo, S.: The IntCal 20 Northern Hemisphere Radiocarbon Age Calibration Curve (0-55 cal kBP), Radiocarbon, 62, 725-757, https://doi.org/10.1017/RDC.2020.41, 2020.

Salvador, P.-G., Berger, J.-F., Fontugne, M., and Gauthier, E.: Etude des enregistrements sédimentaires holocènes des paléoméandres du Rhône dans le secteur des Basses Terres (Ain, Isère, France), Quaternaire, 16, 315-328, https://doi.org/10.4000/quaternaire.517, 2005.

Scapozza, C.: L'evoluzione degli ambienti fluviali del Piano di Magadino dall'anno 1000 a oggi, Arch. Stor. Ticin., 153, 60-92, 2013. 
Scapozza, C.: Appunti climatici e glaciologici sulle descrizioni della Valle di Blenio tra Settecento e Ottocento, Arch. Stor. Ticin., 155, 38-63, 2014.

Scapozza, C.: Evidence of paraglacial and paraperiglacial crisis in Alpine sediment transfer since the Last Glaciation (Ticino, Switzerland), Quaternaire, 27, 139-154, https://doi.org/10.4000/quaternaire.7805, 2016.

Scapozza, C.: Esempi di corrispondenze della suddivisione formale della Serie/Epoca dell'Olocene nella Svizzera italiana, Boll. Soc. Ticin. Sci. Nat., 107, 83-88, 2019.

Scapozza, C. and Ambrosi, C.: Between glaciers, rivers and lakes: the geomorphological landscapes of Ticino, in: Landscapes and Landforms of Switzerland, edited by: Reynard, E., Springer Nature, Cham, Switzerland, 325-336, https://doi.org/10.1007/9783-030-43203-4_22, 2021.

Scapozza, C. and Czerski, D.: Geomorfologia della Svizzera italiana/Die Geomorphologie der Südschweiz, Archeol. Schweiz, 42, 8-13, https://doi.org/10.5169/seals-860436, 2019.

Scapozza, C. and Oppizzi P.: Évolution morphosédimentaire et paléo-environnementale de la plaine fluviodeltaïque du Ticino pendant l'Holocène récent (Canton du Tessin, Suisse), Géomorphologie, 19, 265-286, https://doi.org/10.4000/geomorphologie.10289, 2013.

Scapozza, C., Riff., F., and Schoeneich, P.: Stratigraphie, paléogéographie et dynamique tardiglaciaire du Quaternaire ancien de la Côte entre Gilly et Bursins (VS), Bull. Soc. Vaud. Sc. Nat., 91, 343-361, https://doi.org/10.5169/seals-282157, 2009.

Scapozza, C., Castelletti, C., and Czerski, D.: Nuove datazioni per la storia dell'evoluzione olocenica degli ambienti fluviali del Piano di Magadino (Cantone Ticino, Svizzera), Boll. Soc. Tic. Sci. Nat., 105, 97-102, 2017.

Schoeneich, P.: Le retrait glaciaire dans les vallées des Ormonts, de l'Hongrin et de l'Etivaz (Préalpes vaudoises), Travaux \& Recherches, 14, Institut de Géographie de l’Université de Lausanne, Lausanne, Suisse, p. 483, 1998.
Sormani, M. A.: La necropoli leponzia di Gudo: le tombe golasecchiane (VI-V sec. a. C.), Boll. Stor. Svi. It., 110, 113-134, 2007.

Sormani, M. A.: La necropoli protostorica di Gudo: dall'epoca del Bronzo alla seconda età del Ferro, Boll. Ass. Archeol. Ticin., 24, 4-7, https://doi.org/10.5169/seals-391551, 2012.

Sormani, M. A.: La necropoli protostorica di Gudo: dall'epoca del Bronzo alla seconda età del Ferro, Rivista archeologica dell' antica provincia e diocesi di Como, 193/194, 5-160, 2013.

Strunk, A., Olsen, J., Sanei, H., Rudra, A., and Larsen, N. K.: Improving the reliability of bulk sediment radiocarbon dating, Quaternary Sci. Rev., 242, 106442 , https://doi.org/10.1016/j.quascirev.2020.106442, 2020.

Tinner, W., Hubschmid, P., Wehrli, M., Ammann, B., and Conedera, M.: Long-term forest fire ecology and dynamics in southern Switzerland, J. Ecol., 87, 273-289, https://doi.org/10.1046/j.1365-2745.1999.00346.x, 1999.

Tinner, W., Lotter, A. F., Ammann, B., Conedera, M., Hubschmid, P., van Leeuwen, J. F., and Wehrli, M.: Climatic change and contemporaneous land-use phases north and south of the Alps 2300 BCE to $800 \mathrm{CE}$, Quaternary Sci. Rev., 22, 1447-1460, https://doi.org/10.1016/S0277-3791(03)00083-0, 2003.

UFAM: Rivalutare i corsi d'acqua - per l'uomo e la natura, UFAM - Ufficio federale dell'ambiente, Berna, Svizzera, p. 32, 2017.

Wirth, S. B., Glur, L., Gilli, A., and Anselmetti, F. S.: Holocene flood frequency across the Central Alps - solar forcing and evidence for variations in North Atlantic atmospheric circulation, Quaternary Sci. Rev., 80, 112-128, https://doi.org/10.1016/j.quascirev.2013.09.002, 2013.

Zumbühl, H. J. and Holzhauser, H.: Glaciers des Alpes du Petit âge glaciaire, Les Alpes, 3, 1-322, 1988. 